\title{
Economic Evaluation of Long-Term Survivorship Care for Cancer Patients in OECD Countries: A Systematic Review for Decision-Makers
}

\author{
David Brain * and Amarzaya Jadambaa (D)
}

Citation: Brain, D.; Jadambaa, A. Economic Evaluation of Long-Term Survivorship Care for Cancer Patients in OECD Countries: A Systematic Review for Decision-Makers. Int. J. Environ. Res. Public Health 2021, 18, 11558. https://doi.org/10.3390/ ijerph182111558

Academic Editor: Paul B. Tchounwou

Received: 12 October 2021

Accepted: 26 October 2021

Published: 3 November 2021

Publisher's Note: MDPI stays neutral with regard to jurisdictional claims in published maps and institutional affiliations.

Copyright: (c) 2021 by the authors. Licensee MDPI, Basel, Switzerland. This article is an open access article distributed under the terms and conditions of the Creative Commons Attribution (CC BY) license (https:/ / creativecommons.org/licenses/by/ $4.0 /)$.
Australian Centre for Health Services Innovation, Centre for Healthcare Transformation, School of Public Health and Social Work, Queensland University of Technology, 60 Musk Avenue, Brisbane, QLD 4059, Australia;

a.jadambaa@qut.edu.au

* Correspondence: david.brain@qut.edu.au

\begin{abstract}
Long-term cancer survivorship care is a crucial component of an efficient healthcare system. For numerous reasons, there has been an increase in the number of cancer survivors; therefore, healthcare decision-makers are tasked with balancing a finite budget with a strong demand for services. Decision-makers require clear and pragmatic interpretation of results to inform resource allocation decisions. For these reasons, the impact and importance of economic evidence are increasing. The aim of the current study was to conduct a systematic review of economic evaluations of long-term cancer survivorship care in Organization for Economic Co-operation and Development (OECD) member countries and to assess the usefulness of economic evidence for decision-makers. A systematic review of electronic databases, including MEDLINE, PubMed, PsycINFO and others, was conducted. The reporting quality of the included studies was appraised using the Consolidated Health Economic Evaluation Reporting Standards (CHEERS) checklist. Each included study's usefulness for decision-makers was assessed using an adapted version of a previously published approach. Overall, 3597 studies were screened, and of the 235 studies assessed for eligibility, 34 satisfied the pre-determined inclusion criteria. We found that the majority of the included studies had limited value for informing healthcare decision-making and conclude that this represents an ongoing issue in the field. We recommend that authors explicitly include a policy statement as part of their presentation of results.
\end{abstract}

Keywords: cancer; long-term survivorship; economic evaluation; health economics; systematic review; decision-making; health services

\section{Introduction}

Cancers of all types are a global health concern, and the worldwide impact of cancer is expected to continue to increase in the coming decades [1]. Long-term survivorship care for cancer patients is a crucial component of a well-functioning healthcare system, but the ongoing management of survivors comes at a cost. Improved treatment has accelerated progress against cancer and has driven a record drop in overall cancer mortality, leaving healthcare decision-makers to face multiple challenges [2-5]. Firstly, the current healthcare environment is characterized by finite budgets and high expectations of good health outcomes, where healthcare decision-makers are required to balance non-increasing budgets with an increased demand for services [6]. This is a challenge for decision-makers who find themselves with an increased number of cancer survivors who require ongoing, long-term support services. Secondly, healthcare decision-makers are required to quickly synthesize evidence from a range of competing disciplines regarding service provision, so the ease with which findings can be translated into practice, or at the very least pragmatically interpreted, is of significant importance to them [7]. Despite increased interest and reliance on economic evidence in healthcare, decision-makers need to understand the potential 
impact of acting on such evidence and how such actions might influence clinical outcomes and costs. Healthcare decision-makers require economic evidence to be high-quality, useful for informing resource allocation decisions, applicable to the real-world healthcare setting and easily translated into practice $[8,9]$.

Systematic reviews of economic evaluations relating to long-term cancer survivorship exist, but they do not focus on the usefulness of reported evidence for decision-making. One review focuses on economic evaluations of follow-up cancer care treatment [9], while another was conducted to identify analyses that have been included in guidance on cancer follow-up by UK government agencies and aimed to assess the relevance to the UK setting [10]. The most recent review (2021) focused only on physical activity interventions for cancer survivors in developed countries [10]. The aim of our study was to conduct a systematic review of the available economic evaluations of long-term survivorship care for cancer patients in OECD countries. Our intention is to support healthcare decision-makers-clinicians, policymakers and budget allocators-by summarizing the best available evidence associated with the provision of long-term cancer survivorship care and assess included studies for both quality and usefulness from a health economics perspective. To our knowledge, this work has not been undertaken elsewhere, and our results add novel information to the evidence base.

\section{Materials and Methods}

This study followed the PRISMA statement [11] for processing and reporting systematic reviews (Tables A1 and A2, Appendix A). The aim of this process was to capture all relevant economic evaluations of long-term survivorship for cancer patients in OECD countries. A review protocol was developed in advance, with search methods and inclusion criteria specified (Table A3, Appendix B).

\subsection{Inclusion and Exclusion Criteria}

This systematic review included studies meeting the following inclusion criteria: (1) reported original empirical research published in a peer-reviewed journal; (2) evaluated the economic impact and health outcomes associated with implementing long-term survivorship care for cancer patients who had initial cancer treatment(s) - any economic evaluation. This may include either model-based or non-model-based economic evaluations such as cost-utility analysis, cost-effectiveness analysis and costing analysis; and (3) the study was conducted in OECD countries. The most widely used definition of cancer survivorship is from the National Coalition for Cancer Survivorship and includes for each person the period 'from the time of diagnosis, through the balance of his or her life, regardless of the ultimate cause of death' [12]. Different stages of survivorship comprise acute (diagnosis to treatment), chronic (ongoing) and long-term/late survivorship ( $\geq 5$ years post-diagnosis) [13]. The target population of this review is cancer patients of any age and gender who have received survivorship care for $\geq 5$ years after initial cancer treatment. As we aimed to include economic evaluations from the payer's perspective, costs related to follow-up care (e.g., direct and indirect medical costs, intervention costs and overhead costs) and any outcome (e.g., recurrence, detected relapse, quality-adjusted life years (QALYs) and life years (LYs)) are reviewed in this review. Studies were excluded if they evaluated follow-up care for hyperplasia/dysplasia or management of chemo/radiotherapy-induced symptoms. Scholarly reviews, letters to the editor, comments, news and conference abstracts were also excluded. In the few instances where the same data were reported across different publications, the most informative article was selected: for example, a study reporting the full set of cost-effectiveness results from a model comparing alternative follow-up schedules for women across four different risk profiles was selected [14] ahead of one providing results that only take into account age and adherence to mammography [15]. Final decisions regarding the inclusion or exclusion of studies were made based on a consensus between both reviewers (A.J. and D.B.). The full inclusion and exclusion criteria used for selection of the studies included in this review 
are shown in the protocol published in PROSPERO (ID: CRD42020218966) as well as in Appendix B.

\subsection{Search Strategy}

Five electronic databases, namely MEDLINE, PubMed, PsycINFO, National Health Service Economic Evaluation Databases and Health Technology Assessment Databases, were searched to identify studies conducting an economic evaluation of long-term survivorship care for cancer survivors in OECD countries. The following search terms were used: "economic evaluation" or "economic analys" or "cost" and "follow-up" or "survivorship care" or "long-term strateg*" and cancer* or carcinoma* or neoplasm*. The search was restricted to the English language and by publication period between 1 January 2000 and 12 November 2020. The reference lists of included studies were searched for other relevant studies.

\subsection{Data Extraction and Quality Assessment}

After preliminary screening of the title and abstract, articles deemed relevant were retrieved for examination. Data extraction sheets were pilot tested and revised to include the data source, study design, period of publication, location, sample size, age group, type of cancer, intervention/comparator, type of economic evaluation, presence of sensitivity analysis and main results (Table A5, Appendix C).

The quality of each study was assessed using the Consolidated Health Economic Evaluation Reporting Standards (CHEERS) statement [16]. The 24-item checklist is a consolidation and update of previous reporting guidelines and consists of recommendations on reporting methods and findings for economic evaluations (Appendix D). It also provides an example to ensure more consistency and transparency when reporting results and can be used as a way of comparing studies. Each item in the checklist was scored as having either met the criteria in full (1), partially (0.5) or not at all (0) or as not being applicable (NA). Overall compliance with the checklist was assessed by calculating the proportion of the CHEERS criteria addressed by the study. Fully meeting the criteria would contribute 1 to the numerator while partially meeting the criteria would contribute 0.5 to the numerator. Any criteria that were not applicable to the study were excluded from the denominator. The quality assessment for each study is presented in Appendix D. While examining the analysis type and findings according to the CHEERS checklist is performed to assess the quality of reporting [17], checking the usefulness to decision-makers is arguably of greater importance [9]. Consequently, we used an adapted version of the approach that has been used in previous systematic reviews to assess a paper's usefulness to decision-makers [8,9]. This approach assesses usefulness for decision-makers based on the reporting of effectiveness and cost outcomes and the uncertainty associated with such outcomes. We also searched for a clear statement regarding policy implications or directions that should be followed as a result of the study's outcomes, culminating in an overall usefulness rating of "limited", "moderate" or "strong". These ratings can be seen in Table for Usefulness of reviewed studies to decision-making.

\section{Results}

A total of 4404 articles were identified in the electronic database search, of which 807 were duplicates. The titles and abstracts of 3597 unduplicated references were reviewed and a further 3369 articles were excluded. Seventeen records were identified from additional sources. Reports were not retrieved for 10 studies. Of the 235 studies assessed for eligibility, 34 satisfied the pre-determined inclusion criteria (Figure 1). 


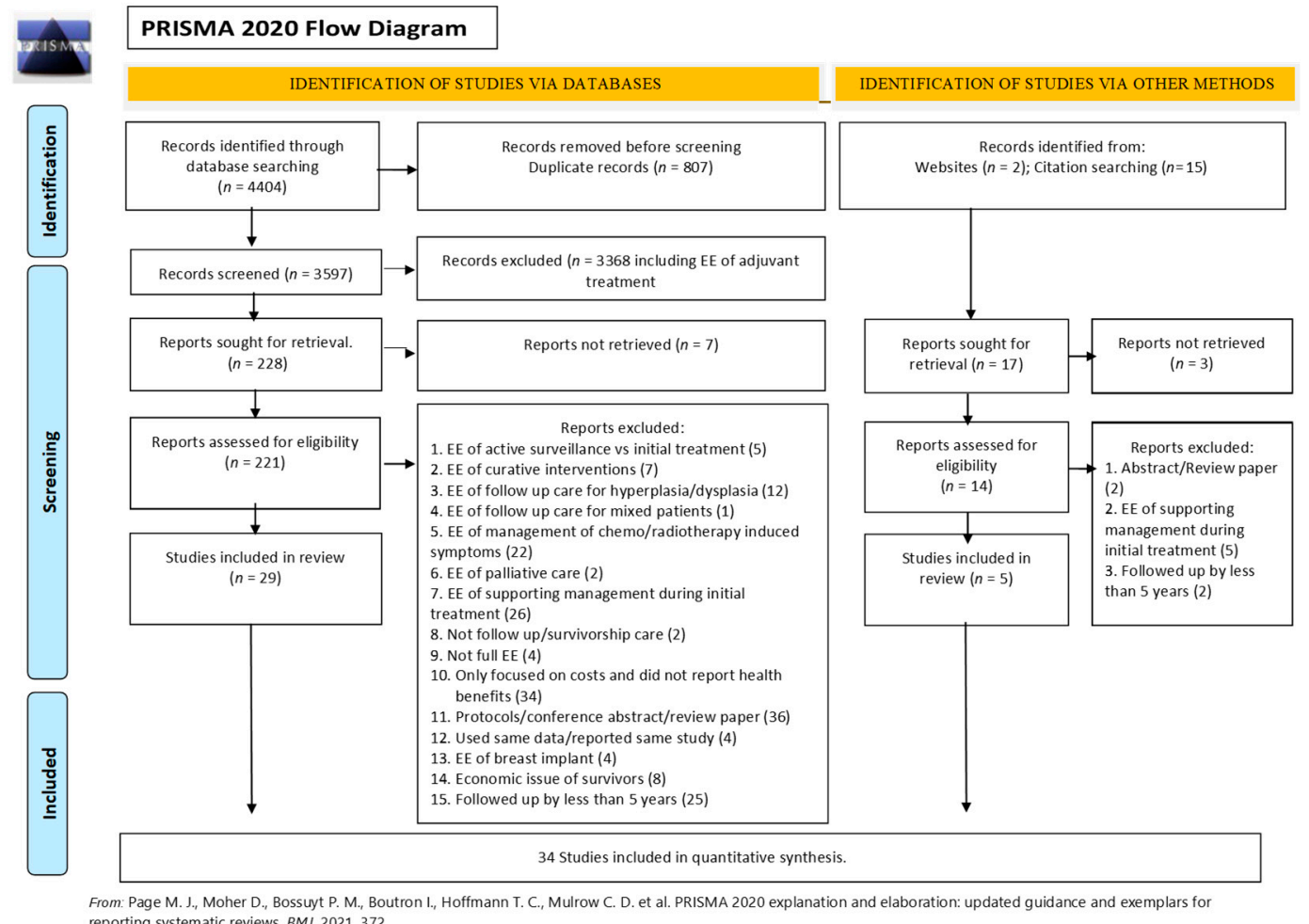

Figure 1. PRISMA flow diagram showing the process of study selection for inclusion in the systematic review.

\subsection{Overview of Included Studies}

Table 1 provides an overview of the descriptive information of the 34 included studies. Studies from the UK and USA were the most common, and almost half the studies retrospectively analyzed cost and effectiveness data. The majority of the studies evaluated survivorship care for colorectal and breast cancer survivors. Twenty out of the 34 included studies were published before 2013, which is when the CHEERS checklist became available [16].

Table 1. Descriptive information of included studies.

\begin{tabular}{cc}
\hline Descriptive Variable & Number of Studies \\
\hline & Study design \\
\hline Retrospective data audit & 13 \\
Markov model & 9 \\
Other models & 6 \\
Randomized control trial & 1 \\
Decision tree model & 1 \\
Discrete event simulation model & 1 \\
Mixed: decision tree + Markov model & 1 \\
Quasi-experimental pre/post-study & 2 \\
\hline Study Location & \\
UK & 6 \\
USA & 5 \\
Germany & 4 \\
Australia & 4 \\
Canada & 4 \\
Italy & $3^{*}$ \\
Netherlands & 3 \\
Sweden & 1 \\
\hline
\end{tabular}


Table 1. Cont.

\begin{tabular}{|c|c|}
\hline Descriptive Variable & Number of Studies \\
\hline France & 1 \\
\hline Finland & 1 \\
\hline Ireland & 1 \\
\hline Spain & 1 \\
\hline Switzerland & 1 * \\
\hline \multicolumn{2}{|c|}{ Type of cancer } \\
\hline Colorectal & 7 \\
\hline Breast & 6 \\
\hline Cutaneous melanoma & 3 \\
\hline Cervical & 3 \\
\hline Head and neck & 2 \\
\hline Hodgkin's disease & 2 \\
\hline Testicular cancer & 2 \\
\hline Prostate & 1 \\
\hline Hematological malignancy & 1 \\
\hline Bladder & 1 \\
\hline Lung & 1 \\
\hline Ovarian & 1 \\
\hline Renal & 1 \\
\hline Thyroid & 1 \\
\hline Uterine & 1 \\
\hline Not mentioned (childhood cancer) & 1 \\
\hline \multicolumn{2}{|c|}{ Publication year (CHEERS checklist became available after 2013) } \\
\hline Before 2013 & 20 \\
\hline After 2013 & 14 \\
\hline
\end{tabular}

* One study collected data from participants from both countries, total number exceeds 34; CHEERS

-Consolidated Health Economic Evaluation Reporting Standards.

The study characteristics of all included studies are summarized in Appendix C. Most studies $(n=12)$ were cost-effectiveness analyses (CEAs), followed by costing-only studies and cost-consequence analyses (CCAs) $(n=11)$, cost-utility analyses (CUAs, $n=9)$ and cost minimization analyses (CMAs, $n=2)$. The outcome measures used in these studies varied according to the study type and design. Ten of the 18 studies that used decision analytic models reported outcomes using incremental cost-effectiveness ratios (ICERs)—calculated by dividing the difference in cost between two alternatives for survivorship care by the difference in their effectiveness. Other studies reported cost per QALY gained, cost per cancer recurrence or change in costs and outcomes separately rather than in a ratio.

\subsection{Studies of Long-Term Survivorship Care by Cancer Type}

For descriptive purposes, the studies were divided into eight groups depending on the disease condition of interest. These eight groups were colorectal cancer, breast cancer, skin cancer, cervical cancer, head and neck cancer, Hodgkin's disease, testicular cancer and other cancers.

\subsubsection{Colorectal Cancer}

Seven studies assessed the cost-effectiveness of long-term survivorship care in patients previously treated for colorectal cancer. Three were retrospective data analyses [18-20] and the remaining four were model-based [21-24]. Staib et al. [20] estimated the cost per recurrence detected through the existing intensive follow-up strategy in the German setting, which was estimated to be EUR 6000 from a hospital perspective. Bleeker et al. [18] compared the value and effectiveness of different diagnostic tools used to identify potentially treatable recurrences among Dutch patients. They concluded that carcinoembryonic antigen testing (CeA), chest radiography and routine physician visits appear less cost-effective than ultrasonography, computed tomography (CT) and colonoscopy, which can identify 
most recurrences at a lower health system cost. However, no sensitivity analysis was conducted to test the robustness of the outcomes of these two studies. Borie et al. [21] built a Markov model to compare standard and simplified follow-up examinations for patients after curative colorectal cancer resection in France and found that the ICER for standard versus simplified follow-up would be EUR 3114, substantially lower than the current threshold of acceptability in France (EUR 105,656/QALY) [25]. Renehan et al. [24] developed a model to compare an intensive follow-up strategy with a conventional strategy for colorectal cancer survivors of 5 years or more from the UK NHS perspective. They found that the cost per life year gained was GBP 3402-substantially lower than the NHS threshold for cost-effectiveness, which is GBP 30,000. In another UK study, Macafee et al. [22] used retrospective data for a five-year projection comparing an intensive follow-up strategy with a standard follow-up strategy, concluding that an intensive follow-up would cost an additional GBP 15.4 million over 5 years, with a cost per additional resectable recurrence of GBP 18,077. An Italian study compared several combinations of diagnostic tests for follow-up of patients after curative resection of colorectal cancer [19]. The combination of physical examination, rigid sigmoidoscopy, thorax-abdominal CT and CeA testing was found to be the most cost-effective strategy to monitor stage III and IV colorectal cancer, while physical examination, colonoscopy, thorax-abdominal CT and CeA testing were found to be the most cost-effective methods to monitor stages I and II of colon cancer. Finally, in a more recent UK study, Mant et al. [23] conducted a randomized control trial (RCT) and built a pre-trial economic model to compare different follow-up strategies from the UK NHS perspective. They found that the incremental cost per patient, compared with the less intensive care, ranged from GBP 40,131 with CeA testing to GBP 43,392 with hospital-based imaging to GBP 85,151 with CeA testing and CT combined.

\subsubsection{Breast Cancer}

Six studies assessed the cost-effectiveness of long-term survivorship care in patients previously treated for breast cancer: one was an RCT, two assessed retrospective audit data and the remaining two were model-based studies. In an Australian study, Grogan et al. [26] retrospectively assessed the costs and effectiveness of several follow-up schedules for women diagnosed with stage I or II breast cancer. They found that three-monthly visits for 4 years and yearly visits in the fifth year cost AUD 1097 per woman. This was a more costeffective option compared to monthly visits for 5 years, which was more expensive at AUD 3870 per patient. Kokko et al. [27] conducted an RCT to compare four follow-up schedules which differed in visit frequency and in the intensity of diagnostic examination. The total cost of follow-up per recurrence was EUR 4983 lower in the least intensive strategy than in the most intensive follow-up strategy. This amount, EUR 4983 per recurrence, could be saved if visits were only every sixth months and diagnostic tests were taken only when clinically indicated compared to quarterly visits and routine diagnostic tests. Robertson et al. [28] built a Markov model, finding that the most cost-effective strategy in the UK setting was surveillance with mammography alone, provided every 12 months. The incremental cost-effectiveness ratio (ICER) for this strategy compared to no surveillance was GBP 4727 per QALY gained. Lu et al. [29] built a simulation model in the Netherlands to compare the cost-effectiveness of the current guideline-based follow-up with three less intensive follow-up strategies. They found that the current guideline-based strategy was the most expensive and the less intensive programs did not decrease the detection rate of small tumors. They concluded that a reduction in hospital follow-up time by shifting to the National Screening Program or the use of general practitioners and the exclusion of physical examination after 2 years of follow-up was the most cost-effective option, with an estimated cost of EUR 62,100 to increase the detection of small tumors by $1 \%$. However, a sensitivity analysis was not conducted to test the robustness of the outcome of these three strategies. An Australian study used a discrete event simulation model to analyze three alternative mammographic follow-up schedules for postmenopausal women who had treatment for primary breast cancer [14]. After conducting a probabilistic sensitivity analysis, the authors 
concluded that for most postmenopausal women, annual mammographic follow-up may not be cost-effective, and for women with excellent tumor prognosis, two-yearly follow-up mammograms are most likely to be cost-effective, regardless of age.

\subsubsection{Skin Cancer}

Three studies assessed the cost-effectiveness of long-term survivorship care in patients previously treated for cutaneous melanoma-one of which retrospectively analyzed data, while the remaining two were model-based studies. Hengge et al. [30] built a Markov model for locoregional recurrence and metastatic recurrence and compared the current intense follow-up strategy with a revised or reduced guideline. The authors found that savings for the 5-year program would total EUR 506,280, and the cost for staging per QALY accounted for EUR 63,252 for the more intense schedule as opposed to EUR 42,433 for the revised, new schedule. The primary outcome of this study was presented as cost per QALY, which enabled direct comparison with other studies. Leiter et al. [31] analyzed retrospective audit data and reported that physical examination was the most effective method, detecting $50 \%$ of recurrences, and gave patients a better quality of life. From the perspective of the payer, a risk-adapted surveillance strategy for stages I to II-including thorough history, physical examination and lymph node sonography but omitting CR, blood work and abdomen sonography-seems appropriate and cost-effective. The costeffectiveness of different radiological examinations was assessed by Podlipnik et al. [32]. Podlipnik et al. [32] built a decision tree model programmed to model a 5-year period and reported that $\mathrm{CT}$ scan was cost-effective in the first 4 years (cost-effectiveness ratio ranged between EUR 4710 and 14,437/patient with metastasis) and brain MRI was cost-effective during the first year (cost-effectiveness ratio of EUR 14,090/patient with metastasis). These results were supported by one-way sensitivity analysis.

\subsubsection{Cervical Cancer}

Three studies assessed the cost-effectiveness of long-term survivorship care in patients previously treated for cervical cancer-two assessed retrospective audit data and one was model-based. An Italian study [33] retrospectively analyzed data on a simplified follow-up diagnostic approach as well as a standard follow-up procedure and reported that a simplified diagnostic approach, which included squamous cell carcinoma (SCC) assay and gynecologic examination, can detect a high rate of recurrence, with a favorable cost-effectiveness outcome. The remaining two studies were conducted in the UK. BaenaCañada et al. [34] assessed the costs, health-related quality of life and patient satisfaction results of follow-up strategies in primary care compared with specialist-led care, reporting that the costs of follow-up in primary care were lower than those in specialist-led care, with no difference recorded in health-related quality of life (HRQoL). No sensitivity analysis was conducted. As a model-based economic evaluation, Auguste et al. [35] used effectiveness data from a systematic review [36] supplemented with data from other sources to run a model over 5 years. With PSA, the researchers concluded that the use of positron emission tomography/computed tomography (PET/CT) in the diagnosis of recurrent or persistent cervical cancer in a secondary care setting is not cost-effective from the NHS perspective.

\subsubsection{Head and Neck Cancer}

Two studies assessed the cost-effectiveness of long-term survivorship care in patients previously treated for head and neck cancer. Shah et al. [37] conducted a retrospective cohort analysis comparing standard follow-up-which consisted of routine clinical follow-up every 3 months for 2 years, every four months in the third year and every six months in the fourth and fifth years-with reduced follow-up - which consisted of routine clinical followup every six months. They found that the hospital cost savings per patient from reduced review were AUD 5012 over five years, while there was no difference in the time to detection of recurrence or proportion of radically treatable recurrences. Meregaglia et al. [38] provided strong evidence on the cost-effectiveness of the use of intensive radiological 
assessment in routine surveillance after treatment for head and neck cancer compared to a more minimal option-symptom-driven surveillance. They reported that routine surveillance with the intensive program would be cost-effective, which was supported by two-way sensitivity analysis. More than two-thirds of the Monte Carlo simulations were below the willingness-to-pay threshold of EUR 40,000, indicating that the intervention was cost-effective.

\subsubsection{Hodgkin's Disease}

Two economic evaluations of long-term survivorship care strategies for patients previously treated for Hodgkin's disease were found. A retrospective review of patients treated for Hodgkin's disease in Canada was performed to evaluate the utility of the components of a follow-up strategy [39]. Dryver et al. [39] concluded that most true relapses are clinically symptomatic, and routine $\mathrm{CT}$ is an expensive and inefficient mode of routine follow-up. Supporting these findings were the results from an American study that found that the use of CT in routine follow-up for patients diagnosed at any stage of disease was less effective and more costly than non-CT modalities [40].

\subsubsection{Testicular Cancer}

Two economic evaluations of long-term survivorship care strategies for patients previously treated for testicular cancer were found. Clasen et al. [41] analyzed the value of routine post-treatment follow-up strategies for patients with seminoma after radiotherapy and reported that abdominal sonography had the highest cost-efficiency among all technical follow-up investigations in the German setting. Charytonowicz et al. [42] built a Markov model to simulate the impact of the miRNA test on testicular germ cell tumor (TGCT) aftercare costs and found that applying this model to the US healthcare system by replacing CT scans with the miRNA test has the potential to save up to USD 69 million per year in aftercare expenses related to TGCT treatment, with exact savings depending on the adoption rate and test price.

\subsubsection{Others}

Nine additional records on long-term survivorship care strategies for other cancer types were found-five assessed retrospective audit data and four studies used a decision analytic model. In a Canadian study, Gilbert et al. [43] assessed the costs and effectiveness of follow-up surveillance after limited-stage non-small cell lung cancer resection and found that the cost per recurrence detected by a thoracic surgeon is higher than that from using a family physician. The costs of two surveillance strategies in patients after radical nephrectomy for localized primary renal cell carcinoma (RCC) were evaluated in a Canadian retrospective cohort study [44]. Dion et al. [44] concluded that the new Canadian Urological Association surveillance strategy in RCC follow-up was appropriate and cost-effective in comparison with older follow-up strategies. In an American study, Rettenmaier et al. [45] reviewed the surveillance of uterine cancers and found that the CA-125 assay appeared to be the most cost-effective method in following patients with epithelial uterine malignancies compared to serial imaging, vaginal cytology and imaging in the follow-up of uterine cancer. Additionally, the CA-125 assay appeared to be the most cost-effective method in following patients with ovarian cancer and/or primary peritoneal cancer (PPC) compared to CT imaging, vaginal cytology and imaging in the longterm follow-up strategy [46]. Imran et al. [47] compared outcomes and costs for low-risk thyroid cancer patients followed by multidisciplinary clinics in tertiary clinics versus those discharged at 24 months for follow-up in the primary care setting in Canada and reported that the rates of recurrence were similar in both groups, while both healthcare costs and travel costs related to primary care were lower than those in tertiary care. The researchers of these five studies conducted retrospective data analyses without a sensitivity analysis.

Dansk et al. [48] built a mixed model to assess the economic impact of using hexaminolevulinate hydrochloride-guided blue-light flexible cystoscopy (HAL BLFC) compared 
with using white-light flexible cystoscopy (WLFC) alone in the follow-up strategy for patients after successful initial transurethral resection of bladder cancer to detect recurrence in Sweden. The authors concluded that HAL BLFC allowed more outpatient treatment, improved recurrence detection, reduced transurethral resection of bladder tumors and reduced cystectomies, bed days and operating room time with minimal cost impact across all risk groups. A Markov model was built to investigate the cost of three different follow-up strategies for prostate cancer patients treated with curative intent in the Irish setting [49]. Pearce et al. [49] conducted a cost minimization analysis, and the results were supported by a one-way sensitivity analysis and PSA. They found that the current Irish practice was the least cost-efficient option for prostate cancer follow-up care, while the implementation of alternative models of care such as the NICE guidelines would lead to significant cost savings in the Irish healthcare system. An economic model from Australia compared the implementation of a dietary modification counselling service and individually tailored community-based physical activity programs to a scenario where no lifestyle program is implemented for the survivors of hematological malignancy treated with hemopoietic stem cell transplantation [50]. The authors concluded that the intervention is more likely to be cost-effective for people who were overweight/obese at the baseline. In the USA, a microsimulation model was built to estimate the long-term health and economic outcomes associated with recommended routine cardiography screening for survivors of childhood cancer treated with anthracycline chemotherapy or chest-directed radiotherapy [51]. Childhood cancer survivors who are treated with anthracycline chemotherapy or radiotherapy are at increased risk of developing cardiomyopathy [52]. Ehrhardt et al. [51] found that given the USD 100,000 per QALY gained threshold for cost-effectiveness, screening at 2-, 5and 10-year intervals appears to be cost-effective for high-risk survivors, and every 5 and 10 years for moderate-risk survivors. Screening every 10 years for low-risk survivors does not appear to be cost-effective.

\subsection{Quality Assessment}

The methodology for assessing the quality of reporting, presented in Appendix D, describes the quality assessment procedure and the compliance with the CHEERS checklist for each study. As previously mentioned, 14 out of the 34 included studies were published after 2013 when the CHEERS checklist became available [16]. Compliance with the CHEERS checklist ranged from 45 to $98 \%$. One out of the seven studies that achieved more than 90\% compliance was published before 2013 [28]. None of the included studies addressed every item listed in the checklist. All studies adequately reported elements relating to background, target population, setting, estimating resources/costs and currency, price date and conversion. For the 16 non-model-based studies, items relating to discount rate, model choice, measurement and valuation of preference-based outcomes, assumptions and description of analytic methods were not applicable. The most poorly reported items related to characterizing uncertainty and heterogeneity.

Time horizon refers to the period over which costs and outcomes are being evaluated. We included studies that evaluated costs and outcomes for a period of 5 years or more. Less than half $(14 / 34)$ of the included studies stated why their choice of time horizon was appropriate for the study.

Non-model-based economic evaluations did not apply discounting to costs and health consequences and did not thoroughly describe the underlying assumptions or analytical methods used in the evaluation. Five out of the 18 model-based studies did not apply a discounting rate or did not report the use of a discount rate, with only one study explaining why this was appropriate [32]. Six out of the 13 model-based studies where discount rates were applied did not justify the chosen discount rate.

For an economic evaluation, effectiveness refers to the ability of an intervention to provide the desired clinical outcome, which is assessed in item 11 of the checklist. Eight studies, including one non-model-based study, met this criterion. The non-model-based 
study performed a literature search and described the methods used for the identification of the included studies and the synthesis of clinical effectiveness data [20].

\subsection{Usefulness of Economic Evaluation Studies to Decision-Makers}

In assessing the usefulness of the reports, we found that having a high compliance score to the CHEERS reporting checklist does not necessarily guarantee that the study is of great use in decision-making. The summary data extracted in relation to the usefulness of each study are shown in Table 2. Six studies used Markov (state-based) models, one used a decision tree, one study used both a Markov model and a decision tree, while one used discrete event simulation as the model structure. A further six studies used other types of models-namely an empirical model, a validated simulation model, a microsimulation model, a pre-trial economic model and a 5-year projection model. Studies were categorized as having either a "strong", "moderate" or "limited" level of usefulness for decision-makers. In judging the reporting, we were looking for a clear direction or suggestion about how the results of the analysis could be used to improve the efficiency of healthcare resource use. Seven studies made a clear statement about changing or keeping the allocation of resources or explained how the study's outcomes are relevant to policies. Ultimately, only one study was rated as "strongly" useful for decision-makers and five studies were rated to be of "moderate" usefulness, while the remaining studies were rated as having "limited" usefulness for decision-makers. The study rated as "strongly" useful was a CUA which utilized a microsimulation model [51], while the studies rated as having "moderate" usefulness were CEAs and CUAs that used a Markov model structure $(n=3)[35,40,50]$, discrete event simulation $(n=1)$ [14] or a 5-year trial model $(n=1)$ [24].

Table 2. Usefulness of reviewed studies to decision-making *.

\begin{tabular}{|c|c|c|c|c|c|c|c|c|}
\hline \multirow[b]{2}{*}{ Study } & \multicolumn{7}{|c|}{ Reasons } & \multirow[b]{2}{*}{$\begin{array}{c}\text { Level of } \\
\text { Usefulness } \\
\text { (Strong/Moderate/ } \\
\text { Limited) }\end{array}$} \\
\hline & $\begin{array}{l}\text { Model- } \\
\text { Based } \\
\text { Design }\end{array}$ & $\begin{array}{c}\text { Applied } \\
\text { Model } \\
\text { Calibration }\end{array}$ & $\begin{array}{l}\text { Direct and } \\
\text { Indirect Costs } \\
\text { Included }\end{array}$ & $\begin{array}{l}\text { Quality of } \\
\text { Life } \\
\text { Measure }\end{array}$ & $\begin{array}{l}\text { Outcome } \\
\text { Presented } \\
\text { as ICER }\end{array}$ & $\begin{array}{c}\text { Full Sensitivity } \\
\text { Analysis (More } \\
\text { than Two } \\
\text { Combination of } \\
\text { OW, MW, PSA, TA } \\
\text { and SA) }\end{array}$ & $\begin{array}{l}\text { Policy Sugges- } \\
\text { tion/Direction }\end{array}$ & \\
\hline \multicolumn{9}{|c|}{ Colorectal cancer } \\
\hline Staib et al. [20] & No & NA & No (direct only) & No & No & NA & No & Limited \\
\hline Bleeker et al. [18] & No & NA & No (direct only) & No & No & NA & No & Limited \\
\hline Borie et al. [21] & Yes & No & No (direct only) & Yes & Yes & No (only OW) & Yes & Limited \\
\hline Renehan et al. [24] & Yes & No & Yes & No & Yes & Yes $(\mathrm{OW}+\mathrm{SA})$ & Yes & Moderate \\
\hline \multirow{3}{*}{$\begin{array}{l}\text { Macafee et al. [22] } \\
\text { Di Cristofaro } \\
\text { et al. [19] } \\
\text { Mant et al. [23] }\end{array}$} & Yes & No & No (direct only) & No & No & No (only SA) & No & Limited \\
\hline & No & NA & No (direct only) & No & No & NA & No & Limited \\
\hline & Yes & No & No (direct only) & Yes & Yes & Yes $(\mathrm{SA}+\mathrm{TA})$ & No & Limited \\
\hline \multicolumn{9}{|c|}{ Breast cancer } \\
\hline Grogan et al. [26] & Yes & No & No (direct only) & No & No & Not conducted & No & Limited \\
\hline Kokko et al. [27] & No & $\mathrm{Na}$ & No (direct only) & No & No & NA & No & Limited \\
\hline Robertson et al. [28] & Yes & No & No (direct only) & Yes & Yes & Yes $(\mathrm{OW}+\mathrm{MW}+\mathrm{TA})$ & No & Limited \\
\hline Lu et al. [29] & Yes & No & No (direct only) & No & No & Not conducted & No & Limited \\
\hline Bessen et al. [14] & Yes & Yes & No (direct only) & Yes & Yes & Yes (SA + PSA) & No & Moderate \\
\hline Draeger et al. [53] & No & NA & No (direct only) & No & No & NA & No & Limited \\
\hline \multicolumn{9}{|c|}{ Skin cancer } \\
\hline Hengge et al. [30] & Yes & No & No (direct only) & Yes & No & Not conducted & Yes & Limited \\
\hline Leiter et al. [31] & No & NA & No (direct only) & No & No & NA & No & Limited \\
\hline Podlipnik et al. [32] & Yes & No & No (direct only) & No & No & Yes $(\mathrm{OW}+\mathrm{SA})$ & No & Limited \\
\hline \multicolumn{9}{|c|}{ Cervical cancer } \\
\hline \multirow{3}{*}{$\begin{array}{l}\text { Forni et al. [33] } \\
\text { Baena-Cañada } \\
\text { et al. [34] } \\
\text { Auguste et al. [35] }\end{array}$} & No & NA & No (direct only) & No & No & NA & No & Limited \\
\hline & No & NA & No (direct only) & Yes & No & NA & No & Limited \\
\hline & Yes & No & No (direct only) & Yes & Yes & Yes (OW + SA + PSA) & Yes & Moderate \\
\hline \multicolumn{9}{|c|}{ Head and neck cancer } \\
\hline Shah et al. [37] & No & NA & No (direct only) & No & No & NA & No & Limited \\
\hline Meregaglia et al. [38] & Yes & No & No (direct only) & Yes & Yes & Yes (OW + TW + PSA) & No & Limited \\
\hline
\end{tabular}


Table 2. Cont.

\begin{tabular}{|c|c|c|c|c|c|c|c|c|}
\hline \multirow[b]{2}{*}{ Study } & \multicolumn{7}{|c|}{ Reasons } & \multirow[b]{2}{*}{$\begin{array}{c}\text { Level of } \\
\text { Usefulness } \\
\text { (Strong/Moderate/ } \\
\text { Limited) }\end{array}$} \\
\hline & $\begin{array}{l}\text { Model- } \\
\text { Based } \\
\text { Design }\end{array}$ & $\begin{array}{c}\text { Applied } \\
\text { Model } \\
\text { Calibration }\end{array}$ & $\begin{array}{l}\text { Direct and } \\
\text { Indirect Costs } \\
\text { Included }\end{array}$ & $\begin{array}{l}\text { Quality of } \\
\text { Life } \\
\text { Measure }\end{array}$ & $\begin{array}{l}\text { Outcome } \\
\text { Presented } \\
\text { as ICER }\end{array}$ & $\begin{array}{c}\text { Full Sensitivity } \\
\text { Analysis (More } \\
\text { than Two } \\
\text { Combination of } \\
\text { OW, MW, PSA, TA } \\
\text { and SA) }\end{array}$ & $\begin{array}{l}\text { Policy Sugges- } \\
\text { tion/Direction }\end{array}$ & \\
\hline \multicolumn{9}{|c|}{ Hodgkin's disease } \\
\hline \multirow{2}{*}{$\begin{array}{l}\text { Dryver et al. [39] } \\
\text { Guadagnolo } \\
\text { et al. [40] }\end{array}$} & No & NA & No (direct only) & No & No & NA & Yes & Limited \\
\hline & Yes & No & No (direct only) & Yes & Yes & Yes $(\mathrm{OW}+\mathrm{SA})$ & Yes & Moderate \\
\hline \multicolumn{9}{|c|}{ Testicular cancer } \\
\hline \multirow{2}{*}{$\begin{array}{l}\text { Clasen et al. [41] } \\
\text { Charytonowicz } \\
\text { et al. [42] }\end{array}$} & No & NA & No (direct only) & No & No & NA & No & Limited \\
\hline & Yes & No & No (direct only) & No & No & No (only OW) & Yes & Limited \\
\hline \multicolumn{9}{|c|}{ Others } \\
\hline Gilbert et al. [43] & No & NA & No (direct only) & No & No & NA & No & Limited \\
\hline Dion et al. [44] & No & NA & No (direct only) & No & No & NA & No & Limited \\
\hline $\begin{array}{c}\text { Rettenmaier } \\
\text { et al. [45] }\end{array}$ & No & NA & No (direct only) & No & No & NA & No & Limited \\
\hline $\begin{array}{l}\text { Rettenmaier } \\
\text { et al. }\end{array}$ & No & NA & No (direct only) & No & No & NA & No & Limited \\
\hline Imran et al. [47] & No & NA & No (direct only) & No & No & NA & Yes & Limited \\
\hline Dansk et al. [48] & Yes & No & No (direct only) & No & No & No (only SA) & Yes & Limited \\
\hline Pearce et al. [49] & Yes & No & No (direct only) & No & No & Yes (OW + PSA) & Yes & Limited \\
\hline Gao et al. [50] & Yes & No & Yes & Yes & Yes & Yes (OW + PSA) & No & Moderate \\
\hline Ehrhardt et al. [51] & Yes & Yes & Yes & Yes & Yes & Yes (OW + TW) & Yes & Strong \\
\hline
\end{tabular}

NOTE. NA: Due to its nature, an item was not relevant to this study. Strong: "Yes" to all items; Moderate: "No" or "NA" or "Not conducted" to one or two items; Limited: "No" or "NA" or "Not conducted" to more than two items. * Adapted from Cheng et al. [8] and McCreanor et al. [9] with copyright permission for use obtained from the corresponding authors. ICER-Incremental Cost-Effectiveness Ratio; OW-One-Way; MW-Multi-Way; PSA-Probabilistic Sensitivity Analysis; TA_Threshold Analysis; SA-Scenario Analysis.

\section{Discussion}

The review systematically collated the published economic evaluation studies on long-term cancer survivorship care in OECD countries and identified 34 studies published between January 2000 and November 2020. More than one-third of the included studies evaluated survivorship care for colorectal and breast cancer (13/34). Half of the included studies were modeling studies (16/34). Assessing economic evaluations regarding longterm survivorship care for patients who have had cancer is not an easy task for multiple reasons that limit comparison. Firstly, the technology used for detecting and monitoring recurrence varies widely according to the cancer type that is being recovered from. Secondly, the different follow-up regimens that are possible are also very different according to the type of cancer that has been survived. Thirdly, not all papers report outcomes in the same way, which is an understandable and reasonable difference that exists in this field of research.

Numerous different approaches to providing long-term follow-up were found in our search. Hospital vs. community service utilization, follow-up frequency and adherence to guideline-based follow-up vs. bespoke options were the most commonly identified follow-up regimens that were compared, across all cancer groups. Numerous studies found that reducing the number of follow-up visits did not worsen health outcomes and contributed to a reduction in long-term survivorship care costs. These findings were consistent across various cancer types, including lung [43], cervical [33], skin [30] and breast cancer [27], and make intuitive sense given that increased health service utilization is associated with increased costs, regardless of whether the costing perspective is from the individual, the health system or a third-party payer. A small number of studies suggest that specialist attention is not a cost-effective approach to providing long-term follow-up care in comparison to providing services in primary care by non-specialist medical staff or with less reliance on the heavy use of technological support. Baena-Cañada et al. [34] found that primary care-based services were cost-effective for following up patients with cervical cancer, and Imran et al. [47] found that non-specialist follow-up care was feasible 
and beneficial from an economic perspective for low-risk thyroid cancer patients, while Shah et al. [37] and Guadagnolo et al. [40] suggest that reducing follow-up intensity by lowering the number of follow-up assessments with PET-CT reduces costs and does not have a detrimental impact on clinical outcomes for patients with head and neck cancers and Hodgkin's disease, respectively. These findings could be used to support a "less is more" approach to designing follow-up regimens and support the hypothesis that there is possibly an over-servicing associated with long-term follow-up for some cancer survivors.

We found comparison of study results difficult due to the wide variety of methods used and due to differences in how outcomes were reported. A surprising number of studies $(n=10)$ presented results from a costing-only perspective, without the measurement of health effects or outcomes and being identified as only costing studies. A further two studies did not include reference to a clear comparator, meaning that comparative analysis of costs and health effects associated with different approaches to follow-up care was not possible $[31,50]$. The most commonly reported results were presented as cost per healthrelated measure (QALY/LYG/HALY) $(n=11)$, followed by cost per follow-up $(n=10)$ and cost per detected recurrence $(n=9)$. Some papers reported more than one outcome of interest.

Based on the results, it is recommended to conduct model-based economic evaluation studies to support policymakers. As decision-making in healthcare is increasingly including evidence from economic evaluations, we think that the best approach to assess long-term survivorship care for cancer patients is to review the quality of the evidence that is available and assess the quality in the context of what is required for decision-makers to make good decisions. From our review, it is unclear what information is most valued by decisionmakers that are tasked with the difficult job of allocating scarce healthcare resources. What is clear is that the majority of studies (26/34) did not provide a clear policy statement regarding resource allocation, leaving decision-makers to interpret the findings in an uncertain manner. We propose that all economic evaluations should include clear and direct statements about how the results should be interpreted and used by decision-makers so that there is no ambiguity regarding the steps that follow. If there are multiple decisionmakers-for example, stakeholders who have differing information requirements-we suggest that analysts should provide clear statements regarding the results that fit those information requirements. Put simply, analysts who conduct health economic evaluations must be cognizant of their audience and provide a clear and practical interpretation of their results to support good decision-making in the healthcare setting.

\section{Conclusions}

Our review shows that there is no shortage of economic evidence relating to longterm cancer survivorship care. All types of economic evaluations, other than cost-benefit analysis, were represented. However, we found that there is a shortage of clear author recommendations that help healthcare decision-makers make decisions about the allocation of scarce resources. Most papers included in the review lacked a clear and practical policy statement, which is a key step for having evidence inform new policies or influence funding allocation. We believe that this issue can be easily corrected if authors more closely adhere to the following steps in future economic evaluations on this topic. First, we recommend that authors follow the CHEERS checklist to ensure that their methods, assumptions and approach are laid bare. This encourages clear and easily digested reporting of the context and methods. Second, we recommend that authors explicitly include a policy statement as part of their presentation of results. Such statements must be clear and direct, acting as recommendations for those charged with putting evidence into practice. Having undertaken this review, we recommend that decision-makers only ever consider economic evaluations that include quality of life data and/or some other relevant patient outcome of interest, so that changes to costs and health outcomes can be assessed. We also recommend that those conducting economic evaluations clearly recommend one of three options for adoption: (1) adopt without delay, (2) do not adopt or (3) design and 
complete an evaluation plan that allows a clear decision to be made. Finally, based on our review, it is also recommended that policymakers use the findings from decision analytic model-based economic evaluations that are rated as providing "moderately" or "strongly" useful evidence for decision-makers, using criteria that are similar to ours. Following these recommendations will make it easier for decision-makers to use the results for decision-making purposes and bring research findings closer to the decisionmaking table.

Author Contributions: Conceptualization, D.B.; methodology, A.J.; software, A.J.; validation, D.B. and A.J.; formal analysis, A.J.; investigation, A.J.; resources, A.J.; data curation, A.J.; writing—original draft preparation, A.J. and D.B.; writing—review and editing, D.B.; visualization, A.J.; supervision, D.B. All authors have read and agreed to the published version of the manuscript.

Funding: This research received no external funding.

Institutional Review Board Statement: Not applicable.

Informed Consent Statement: Not applicable.

Acknowledgments: Cameron Rutter, Liaison Librarian at the School of Public Health and Social Work, Queensland University of Technology, is gratefully acknowledged for his contribution to the systematic review.

Conflicts of Interest: The authors declare no conflict of interest.

\section{Appendix A}

Table A1. PRISMA item checklist.

\begin{tabular}{|c|c|c|c|}
\hline Section and Topic & Item \# & Checklist Item & Reported on Page \# \\
\hline \multicolumn{4}{|c|}{ TITLE } \\
\hline Title & 1 & $\begin{array}{l}\text { Identify the report as a systematic review. } \\
\text { ABSTRACT }\end{array}$ & 1 \\
\hline Abstract & 2 & $\begin{array}{l}\text { See the PRISMA } 2020 \text { for Abstract checklist (Table A2). } \\
\text { INTRODUCTION }\end{array}$ & 1 \\
\hline Rationale & 3 & $\begin{array}{l}\text { Describe the rationale for the review in the context of } \\
\text { existing knowledge. }\end{array}$ & 1 \\
\hline Objectives & 4 & $\begin{array}{l}\text { Provide an explicit statement of the objective(s) or question(s) } \\
\text { the review addresses. }\end{array}$ & 1 \\
\hline Eligibility criteria & 5 & $\begin{array}{l}\text { METHODS } \\
\text { Specify the inclusion and exclusion criteria for the review and } \\
\text { how studies were grouped for the syntheses. } \\
\text { Specify all databases, registers, websites, organizations, reference }\end{array}$ & 2 \\
\hline Information sources & 6 & $\begin{array}{l}\text { lists and other sources searched or consulted to identify studies. } \\
\text { Specify the date when each source was last searched or consulted. }\end{array}$ & 2 \\
\hline Search strategy & 7 & $\begin{array}{l}\text { Present the full search strategies for all databases, registers and } \\
\text { websites, including any filters and limits used. }\end{array}$ & 2, Table A3, Appendix B \\
\hline Selection process & 8 & $\begin{array}{l}\text { Specify the methods used to decide whether a study met the inclusion } \\
\text { criteria of the review, including how many reviewers screened each } \\
\text { record and each report retrieved, whether they worked independently } \\
\text { and, if applicable, details of automation tools used in the process. }\end{array}$ & 2, Appendix B \\
\hline Data collection process & 9 & $\begin{array}{l}\text { Specify the methods used to collect data from reports, including } \\
\text { how many reviewers collected data from each report, whether } \\
\text { they worked independently, any processes for obtaining or } \\
\text { confirming data from study investigators and, if applicable, } \\
\text { details of automation tools used in the process. }\end{array}$ & 2, Appendix B \\
\hline Data items & $10 \mathrm{a}$ & $\begin{array}{l}\text { List and define all outcomes for which data were sought. Specify } \\
\text { whether all results that were compatible with each outcome domain in } \\
\text { each study were sought (e.g., for all measures, time points, analyses), } \\
\text { and if not, the methods used to decide which results to collect. }\end{array}$ & 2, Appendices B and C \\
\hline
\end{tabular}


Table A1. Cont.

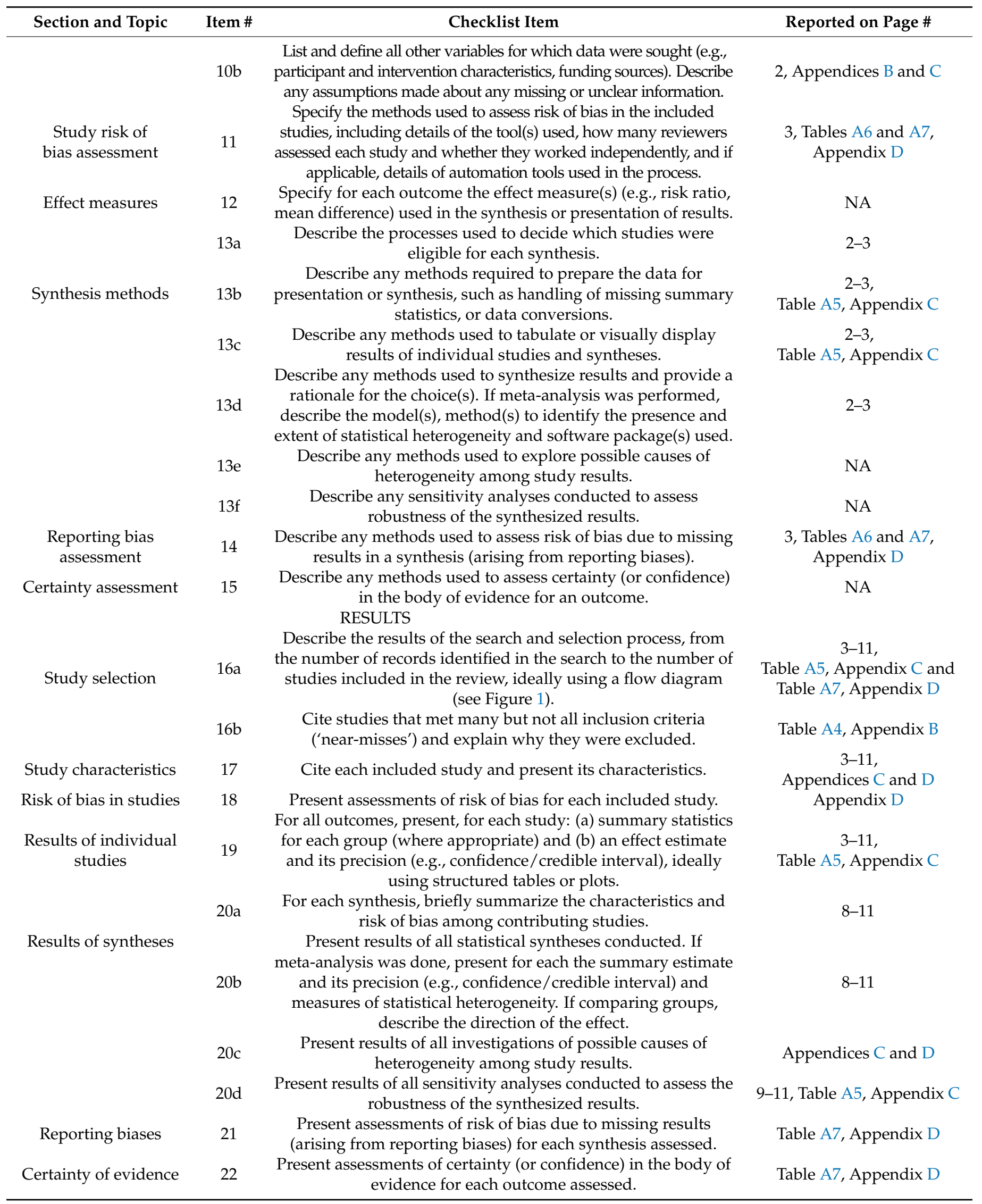


Table A1. Cont.

\begin{tabular}{|c|c|c|c|}
\hline Section and Topic & Item \# & Checklist Item & Reported on Page \# \\
\hline \multirow{5}{*}{ Discussion } & & DISCUSSION & \\
\hline & $23 a$ & $\begin{array}{l}\text { Provide a general interpretation of the results in the context of } \\
\text { other evidence. }\end{array}$ & 11-12 \\
\hline & $23 b$ & Discuss any limitations of the evidence included in the review. & $11-12$ \\
\hline & $23 c$ & Discuss any limitations of the review processes used. & $11-12$ \\
\hline & $23 \mathrm{~d}$ & $\begin{array}{c}\text { Discuss implications of the results for practice, policy and } \\
\text { future research. }\end{array}$ & $11-12$ \\
\hline \multirow{4}{*}{$\begin{array}{l}\text { Registration and } \\
\text { protocol }\end{array}$} & & OTHER INFORMATION & \\
\hline & $24 a$ & $\begin{array}{l}\text { Provide registration information for the review, including } \\
\text { register name and registration number, or state that the review } \\
\text { was not registered. }\end{array}$ & 2 \\
\hline & $24 \mathrm{~b}$ & $\begin{array}{l}\text { Indicate where the review protocol can be accessed, or state that } \\
\text { a protocol was not prepared. }\end{array}$ & 2 \\
\hline & $24 \mathrm{c}$ & $\begin{array}{l}\text { Describe and explain any amendments to information provided } \\
\text { at registration or in the protocol. }\end{array}$ & 2 \\
\hline Support & 25 & $\begin{array}{l}\text { Describe sources of financial or non-financial support for the } \\
\text { review, and the role of the funders or sponsors in the review. }\end{array}$ & NA \\
\hline Competing interests & 26 & Declare any competing interests of review authors. & 12 \\
\hline $\begin{array}{l}\text { Availability of data, } \\
\text { code and other } \\
\text { materials }\end{array}$ & 27 & $\begin{array}{l}\text { Report which of the following are publicly available and where } \\
\text { they can be found: template data collection forms; data } \\
\text { extracted from included studies; data used for all analyses; } \\
\text { analytic code; any other materials used in the review. }\end{array}$ & Appendices A-D \\
\hline
\end{tabular}

Table A2. PRISMA for Abstracts checklist *

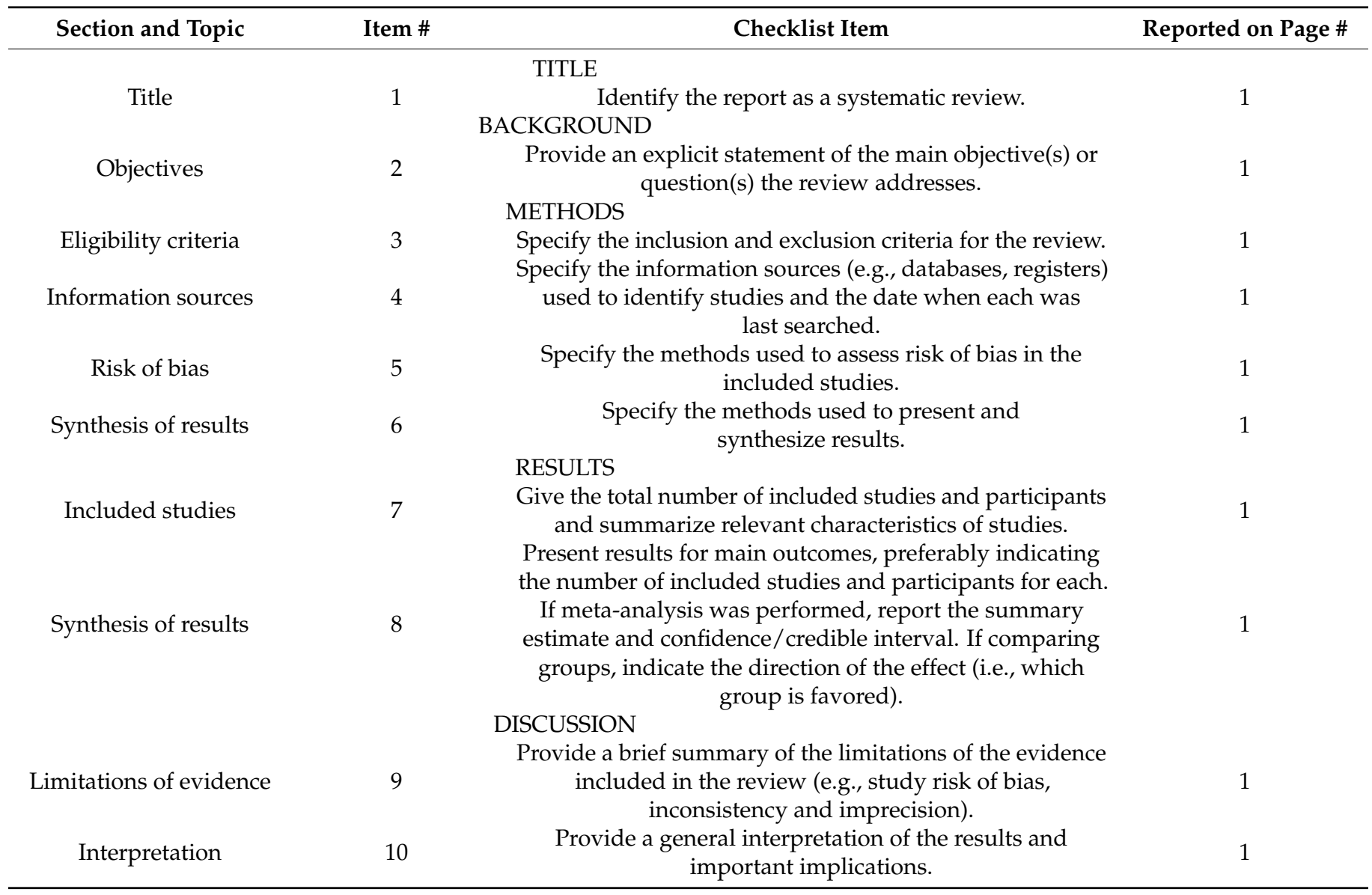


Table A2. Cont.

\begin{tabular}{cccc}
\hline Section and Topic & Item \# & Checklist Item & Reported on Page \# \\
\hline Funding & 11 & OTHER & Specify the primary source of funding for the review. \\
Registration & 12 & Provide the register name and registration number. & NA \\
\hline
\end{tabular}

* This abstract checklist retains the same items as those included in the PRISMA for Abstracts statement published in 2013 but has been revised to make the wording consistent with the PRISMA 2020 statement and includes a new item recommending that authors specify the methods used to present and synthesize results (item \#6).

\section{Appendix B}

Review protocol: Economic evaluation of long-term survivorship care for cancer patients in OECD countries: A systematic review

The review was conducted according to the PRISMA 2020 guidelines [11] and included searches of electronic databases and searching of reference lists. It includes original research focusing on economic evaluations for follow-up strategies of patients previously treated for cancer, including screening for certain issues or the cost-effectiveness of long-term follow-up care/survivorship care.

Data sources: Three electronic databases, namely Medline, PubMed and PsycINFO, and the National Health Service Economic Evaluation Databases as well as the Health Technology Assessment Databases were searched with the assistance of librarians.

Table A3. Search strategy.

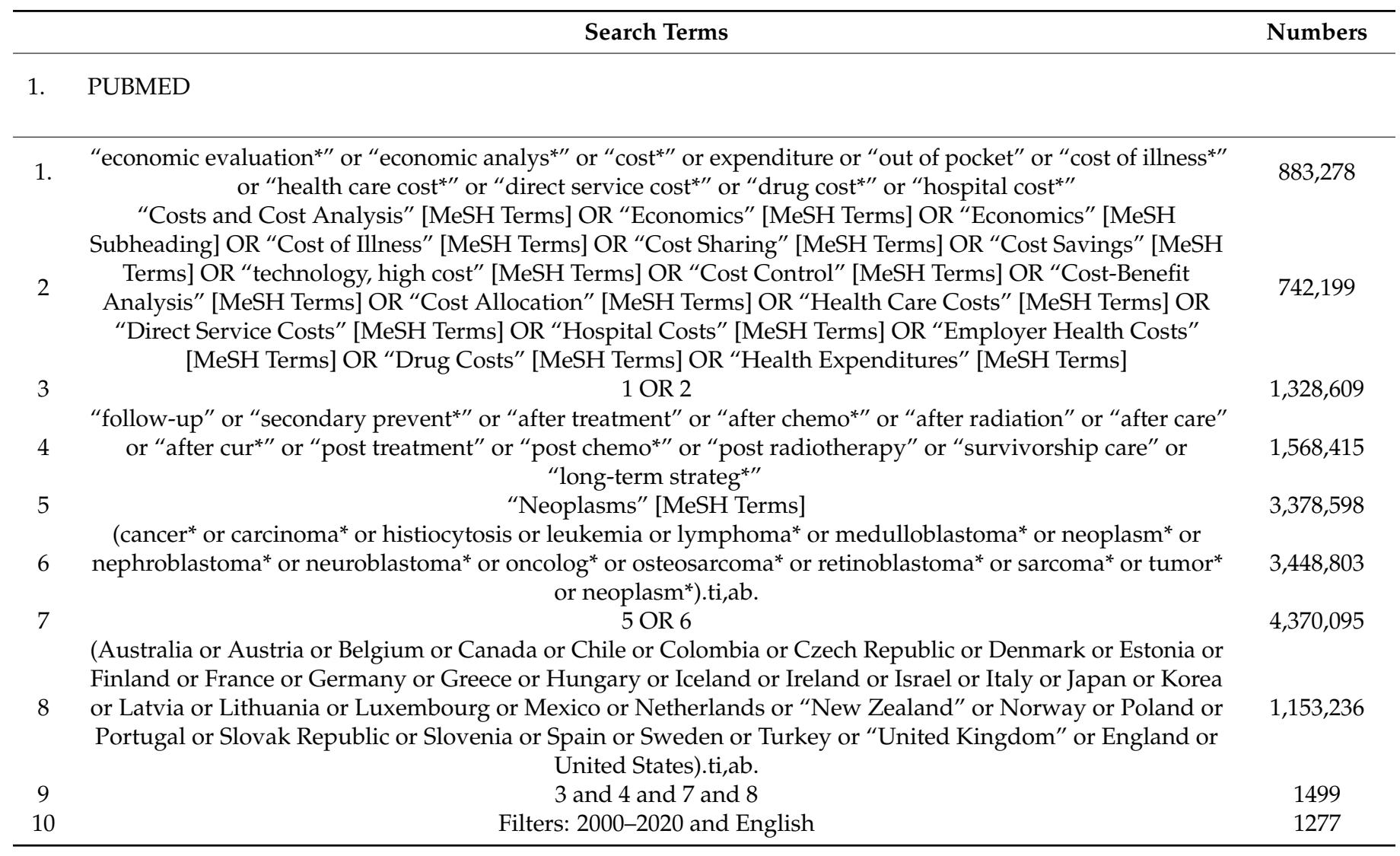


Table A3. Cont.

Search Terms

Numbers

\section{MEDLINE}

("economic evaluation" benefit" or "cost minimization" or "cost minimization" or expenditure or "out of pocket" or "cost of illness" or "health care cost $t^{*}$ " or "direct service cost" or "drug cost $t^{* \prime \prime}$ or "hospital cost $t^{* \prime \prime}$ ) AND ("Follow-up" or "secondary prevent" or "after treatment" or "after chemo" or "after radiation" or "after care" or "after cur*" or "post treatment" or "post chemo*" or "post radiotherapy" or "survivorship care" or "long-term strateg*" or

"short-term strateg*") AND (Cancer* or carcinoma* or histiocytosis or leukemia or lymphoma* or medulloblastoma* or neoplasm* or nephroblastoma* or neuroblastoma* or oncolog* or osteosarcoma* or retinoblastoma* or sarcoma* or tumor* or neoplasm*) AND (Australia or Austria or Belgium or Canada or Chile or Colombia or Czech Republic or Denmark or Estonia or Finland or France or Germany or Greece or Hungary or Iceland or Ireland or Israel or Italy or Japan or Korea or Latvia or Lithuania or Luxembourg or Mexico or Netherlands or "New Zealand" or Norway or Poland or Portugal or Slovak Republic or Slovenia or Spain or Sweden or Turkey or "United Kingdom" or England or United States)Filters: 2000-2020 and English

3. PsychINFO

("economic evaluation*" or "economic analys" or "cost* utility" or "cost analysis" or "cost effective ${ }^{* \prime}$ or "cost benefit" or "cost minimization" or "cost minimization" or expenditure or "out of pocket" or "cost of illness" or "health care cost*" or "direct service cost" or "drug cost" or "hospital cost") AND ("follow-up" or "secondary prevent" or "after treatment" or "after chemo" or "after radiation" or "after care" or "after cur" or "post treatment" or "post chemo"

"short-term strateg*") AND (cancer* or carcinoma* or histiocytosis or leukemia or lymphoma* or medulloblastoma* or neoplasm* or nephroblastoma* or neuroblastoma* or oncolog* or osteosarcoma* or retinoblastoma* or sarcoma* or tumor* or neoplasm*) AND (Australia or Austria or Belgium or Canada or Chile or Colombia or Czech Republic or Denmark or Estonia or Finland or France or Germany or Greece or Hungary or Iceland or Ireland or Israel or Italy or Japan or Korea or Latvia or Lithuania or Luxembourg or Mexico or Netherlands or "New Zealand" or Norway or Poland or Portugal or Slovak Republic or Slovenia or Spain or Sweden or Turkey or "United Kingdom" or England or United States)Filters: 2000-2020 and English

4. National Health Service Economic Evaluation Databases up to 2015

("Follow-up" or "secondary prevent*" or "after treatment" or "after chemo" or "after radiation" or "after care" or "after cur" or "post treatment" or "post chemo*" or "post radiotherapy" or "survivorship care" or "long-term strateg*" or "short-term strateg*") AND (Cancer* or carcinoma* or histiocytosis or leukemia or

lymphoma* or medulloblastoma* or neoplasm* or nephroblastoma* or neuroblastoma* or oncolog* or osteosarcoma* or retinoblastoma* or sarcoma* or tumor* or neoplasm*) AND (Australia or Austria or Belgium or Canada or Chile or Colombia or Czech Republic or Denmark or Estonia or Finland or France or Germany or

Greece or Hungary or Iceland or Ireland or Israel or Italy or Japan or Korea or Latvia or Lithuania or

Luxembourg or Mexico or Netherlands or "New Zealand" or Norway or Poland or Portugal or Slovak

Republic or Slovenia or Spain or Sweden or Turkey or "United Kingdom" or England or United States) Filters: English

5. National Health Service Economic Evaluation Databases

("follow-up" or "secondary prevent" or "after treatment" or "after chemo*" or "after radiation" or "after care" or "after cur*" or "post treatment" or "post chemo*" or "post radiotherapy" or "survivorship care" or "long-term strateg*" or "short-term strateg*") AND (cancer* or carcinoma* or histiocytosis or leukemia or lymphoma* or medulloblastoma* or neoplasm* or nephroblastoma* or neuroblastoma* or oncolog* or osteosarcoma* or retinoblastoma* or sarcoma* or tumor* or neoplasm*) AND (Australia or Austria or Belgium or Canada or Chile or Colombia or Czech Republic or Denmark or Estonia or Finland or France or Germany or

Greece or Hungary or Iceland or Ireland or Israel or Italy or Japan or Korea or Latvia or Lithuania or

Luxembourg or Mexico or Netherlands or "New Zealand" or Norway or Poland or Portugal or Slovak Republic or Slovenia or Spain or Sweden or Turkey or "United Kingdom" or England or United States)

Filters: English

6. From other source: reference list review of any article chosen for possible inclusion 
Question of interest: What is the current cost-effectiveness evidence for long-term survivorship care compared to usual care for cancer patients?

Cancer survivorship: The most widely used definition of cancer survivorship is from the National Coalition for Cancer Survivorship in the USA and includes for each person the period "from the time of diagnosis, through the balance of his or her life, regardless of the ultimate cause of death" [2].

Stages of survivorship: Different stages of survivorship comprise acute (diagnosis to treatment), chronic (ongoing) and long-term/late survivorship ( $\geq 5$ years postdiagnosis) [3].

Population: Cancer patients of any age and sex who have received survivorship care after initial cancer treatment.

Intervention(s), exposure(s):

- Any long-term strategy or any long-term follow-up care or survivorship care ( $\geq 5$ years after initial treatment) as care used in a supportive role to improve quality of life as well as diagnostic strategy to detect recurrence. Types of care that were included in the review were:

Management and/or screening for certain issues such as curable recurrence

Diets, including the use of dietary supplements

Exercise

Counseling

E-health technologies: web-based or app-based e-health interventions

- Fertility treatments

- Any study setting (e.g., hospital- or community-based)

- Any form of recruitment

Comparator(s)/control: Any control group or comparators assigned when comparing an intervention or strategy related to the strategy for cancer survivors as well as no comparator if it is a costing-only study.

Study designs of interest: Prospective and retrospective cohorts, randomized control trials and economic modeling studies.

\section{Inclusion criteria:}

1. Studies that either estimated the impact of survivorship care, comparing it to no survivorship care, or compared different long-term care strategies for cancer survivors in OECD countries

2. Economic evaluations: costing studies, cost-effectiveness analyses, cost-utility analyses, cost-consequences analyses and cost minimization analyses were included if they reported both the costs and benefits expected for both usual care and the comparator(s)

3. Research articles published in English language

4. $\quad$ Research limited to human studies

5. Full publication or manuscript available for review

\section{Exclusion criteria:}

Articles were initially excluded if they were duplicates or if the title clearly demonstrated that the intervention and outcome of interest were not the focus of the review. Articles were then excluded based on the following:

1. Economic evaluation of active surveillance vs. initial treatment (5)

2. Economic evaluation of curative interventions (7)

3. Economic evaluation of follow-up care for hyperplasia/dysplasia (12)

4. Economic evaluation of follow-up care for mixed patients (1)

5. Economic evaluation of management of chemo/radiotherapy-induced symptoms (22)

6. Economic evaluation of palliative care (2)

7. Economic evaluation of supporting management during initial treatment (31)

8. Not follow-up/survivorship care (2)

9. Not economic study (4) 
10. Only focused on costs and did not report health benefits (34)

11. Protocols/conference abstract/review papers (38)

12. Used same data/reported same study (4)

13. Economic evaluation of breast implant (4)

14. Economic issue of survivors (8)

15. Followed up for less than 5 years (27)

Table A4. A list of studies that met many inclusion criteria ("near-misses") but were excluded due to a short follow-up period (less than 5 years).

\begin{tabular}{|c|c|c|}
\hline$\#$ & Study Author and Publication Year & Follow-Up Period \\
\hline \multicolumn{3}{|c|}{ Colorectal cancer } \\
\hline 1 & Augestad et al. [54] & 24 months \\
\hline 2 & Verberne et al. [55] & 3 years \\
\hline \multicolumn{3}{|c|}{ Breast cancer } \\
\hline 3 & Beaver et al. [56] & 24 months \\
\hline 4 & Benning et al. [57] & 12 months \\
\hline 5 & Burm et al. [58] & 9-15 months \\
\hline 6 & Coyle et al. [59] & 24 months \\
\hline 7 & Kimman et al. [60] & 1 year \\
\hline 8 & Oltra et al. [61] & 3 years \\
\hline 9 & Wojcinski et al. [62] & 12 months \\
\hline \multicolumn{3}{|c|}{ Ovarian, uterine cancer } \\
\hline 10 & Armstrong et al. [63] & 2 years \\
\hline 11 & Dixon et al. [64] & 12 months \\
\hline \multicolumn{3}{|c|}{ Head and neck cancer } \\
\hline 12 & Ham et al. [65] & 3.5 months \\
\hline \multicolumn{3}{|c|}{ Others } \\
\hline 13 & Bongers et al. [66] & Mean $(\mathrm{SD})=31.6(9.8)$ months \\
\hline 14 & Greuter et al. [67] & 3 and 6 months \\
\hline 15 & Heinzel et al. [68] & Unclear \\
\hline 16 & Jeyarajah et al. [69] & Mixed 3 and/or 5 years \\
\hline 17 & Kampshoff et al. [70] & 12 weeks \\
\hline 18 & Kent et al. [71] & Up to 5 years \\
\hline 19 & Lizée et al. [72] & 2 years \\
\hline 20 & Moore et al. [73] & 12 months \\
\hline 21 & Nam et al. [74] & Unclear \\
\hline 22 & Polinder et al. [75] & 12 months \\
\hline 23 & Pollack et al. [76] & 366-1095 days \\
\hline 24 & Shih et al. [77] & 6 months \\
\hline 25 & van der Spek et al. [78] & 6 months \\
\hline 26 & van Dongen et al. [79] & 12 months \\
\hline 27 & van Loon et al. [80] & Up to 5 years \\
\hline
\end{tabular}

Main outcome(s): Assess the cost-effectiveness of long-term survivorship care for cancer survivors.

Measures of effect: Incremental effectiveness, incremental costs and ICER (incremental cost-effectiveness ratio) values.

Data extraction: The initial search was performed by two reviewers using predetermined search terms and strategies from chosen databases. All identified papers were imported into EndNote and screened in accordance with PRISMA guidelines.

After removal of duplicates, the titles and abstracts were screened for relevance and eligibility criteria. The two reviewers then extracted the data from the studies selected for 
inclusion using a pre-designed extraction form. The data extraction sheet was first pilot tested on 10 studies and then revised accordingly to include the following.

\section{Identification of study:}

16. Record the first author's last name and initials

17. Record the journal name

18. Record the year of publication

19. Record the volume and page numbers

\section{Characteristics of study:}

20. Setting

21. Type of cancer

22. Patient population (age if available)

23. Intervention

24. Comparator

25. Type of economic evaluation

26. Study design

27. Discount rate

28. Perspective

29. Costs included

30. Time horizon/study period

31. Outcome measures

32. Baseline analysis

33. Sensitivity analysis

34. Main results

35. Additional comments (a threshold value, etc.)

Quality of reporting assessment: The full texts of all included articles were assessed for reporting quality by two independent reviewers using the Consolidated Health Economic Evaluation Reporting Standards (CHEERS) checklist. Any discrepancies over reporting quality assessment between the two reviewers were resolved by discussion with a third reviewer. The standards of the input data for health economic analysis in the decision model were ranked based on the hierarchy adapted by Cooper and colleagues.

Strategy for data synthesis: After screening the title, abstract and full text, data were extracted from relevant articles and were summarized in tables. The data fields were as follows: research question, setting and location, perspective, time horizon, discount rate, structure of the economic model if applied, study population, intervention and comparator, outcome measures, incremental cost-effectiveness ratio (ICER) and sensitivity analysis method.

The quality of the selected economic evaluations was assessed using the Consolidated Health Economic Evaluation Reporting Standards (CHEERS) checklist. This checklist provides 24 items, with accompanying recommendations and examples to ensure more consistency and transparent reporting of economic evaluations. Each item in the CHEERS checklist was scored as having met the criteria in full (1), partially (0.5) or not at all (0) or as not applicable (NA). 


\section{Appendix C}

Table A5. Characteristics of included studies.

\begin{tabular}{|c|c|c|c|c|c|c|c|c|c|c|c|c|c|}
\hline & $\begin{array}{l}\text { Author } \\
\text { (Publica- } \\
\text { tion Year) }\end{array}$ & Setting & $\begin{array}{l}\text { Type of } \\
\text { Cancer }\end{array}$ & Intervention & Comparator & EE Type & $\begin{array}{l}\text { Study } \\
\text { Design }\end{array}$ & $\begin{array}{l}\text { Discount } \\
\text { Rate }\end{array}$ & Perspective & Costs Included & $\begin{array}{l}\text { Time Horizon } \\
\text { Study Period }\end{array}$ & $\begin{array}{l}\text { Outcome } \\
\text { Measures }\end{array}$ & $\begin{array}{c}\text { Sensitivity } \\
\text { Analysis }\end{array}$ \\
\hline 1 & $\begin{array}{l}\text { Staib et al., } \\
\quad(2000)\end{array}$ & Germany & Colorectal & $\begin{array}{l}\text { Intensive } \\
\text { follow-up }\end{array}$ & None & $\begin{array}{l}\text { Costing } \\
\text { study }\end{array}$ & $\begin{array}{l}\text { Retrospective } \\
\text { data audit }\end{array}$ & NA & $\begin{array}{l}\text { Not reported } \\
\text { (health system) }\end{array}$ & $\begin{array}{c}\text { Personnel, } \\
\text { infrastructure } \\
\text { and test costs }\end{array}$ & 10 years & $\begin{array}{l}\text { Cost per followed } \\
\text { cancer patient }\end{array}$ & $\begin{array}{c}\text { Not } \\
\text { conducted }\end{array}$ \\
\hline 2 & $\begin{array}{l}\text { Bleeker } \\
\text { et al., (2001) }\end{array}$ & $\begin{array}{l}\text { The Nether- } \\
\text { lands }\end{array}$ & Colonic & $\begin{array}{l}\text { Mixed } \\
\text { follow-up }\end{array}$ & None & $\begin{array}{l}\text { Costing } \\
\text { study }\end{array}$ & $\begin{array}{l}\text { Retrospective } \\
\text { data audit }\end{array}$ & NA & $\begin{array}{l}\text { Not reported } \\
\text { (health system) }\end{array}$ & $\begin{array}{l}\text { Tests and } \\
\text { examination } \\
\text { costs }\end{array}$ & 43 months & $\begin{array}{l}\text { Cost of follow-up } \\
\text { diagnostic event } \\
\text { per curative } \\
\text { resected } \\
\text { recurrence }\end{array}$ & $\begin{array}{c}\text { Not } \\
\text { conducted }\end{array}$ \\
\hline 3 & $\begin{array}{l}\text { Borie et al., } \\
\quad(2004)\end{array}$ & France & Colorectal & $\begin{array}{l}\text { Standard } \\
\text { follow-up }\end{array}$ & $\begin{array}{l}\text { Simplified } \\
\text { follow-up }\end{array}$ & CUA & Markov Model & NA & $\begin{array}{l}\text { Not reported } \\
\text { (health } \\
\text { system) }\end{array}$ & $\begin{array}{l}\text { The costs of the } \\
\text { examination } \\
\text { carried out }\end{array}$ & 5-7 years & $\Delta$ cost $/ \Delta \mathrm{QALY}$ & OW \\
\hline 4 & $\begin{array}{l}\text { Renehan } \\
\text { et al., (2004) }\end{array}$ & UK & Colorectal & $\begin{array}{l}\text { Intensive } \\
\text { follow-up }\end{array}$ & $\begin{array}{c}\text { Usual } \\
\text { follow-up }\end{array}$ & CEA & $\begin{array}{l}5 \text {-year trail } \\
\text { model }\end{array}$ & $\begin{array}{c}\text { Benefits } \\
1.5 \% \text { and } \\
\text { costs } 6 \%\end{array}$ & $\begin{array}{l}\text { Health service } \\
\text { perspective }\end{array}$ & $\begin{array}{l}\text { Direct, indirect } \\
\text { and overhead } \\
\text { costs }\end{array}$ & 5 years & $\Delta \operatorname{cost} / \Delta \mathrm{LY}$ & OW, SA \\
\hline 5 & $\begin{array}{c}\text { Macafee } \\
\text { et al., (2008) }\end{array}$ & UK & Colorectal & $\begin{array}{l}\text { Intensive } \\
\text { follow-up }\end{array}$ & $\begin{array}{c}\text { Usual } \\
\text { follow-up }\end{array}$ & CEA & $\begin{array}{l}\text { Retrospective } \\
\text { data used } \\
\text { for 5-year } \\
\text { projection }\end{array}$ & Costs $3.5 \%$ & $\begin{array}{l}\text { Hospital } \\
\text { perspective }\end{array}$ & $\begin{array}{l}\text { Direct hospital } \\
\text { costs }\end{array}$ & 5 years & $\begin{array}{l}\text { Cost of follow-up } \\
\text { and cost of re- } \\
\text { sectable recurrence }\end{array}$ & SA \\
\hline 6 & $\begin{array}{l}\text { Di Cristofaro } \\
\text { et al., (2012) }\end{array}$ & Italy & Colorectal & $\begin{array}{l}\text { Multiple } \\
\text { surveillance } \\
\text { protocols }\end{array}$ & None & $\begin{array}{l}\text { Costing } \\
\text { study }\end{array}$ & $\begin{array}{l}\text { Retrospective } \\
\text { data audit }\end{array}$ & NA & $\begin{array}{l}\text { Not reported } \\
\text { (health } \\
\text { system) }\end{array}$ & $\begin{array}{l}\text { Costs for } \\
\text { follow-up tests }\end{array}$ & 5 years & $\begin{array}{l}\text { The costs and the } \\
\text { percentage of recur- } \\
\text { rence following the } \\
\text { various surveillance } \\
\text { protocols } \\
\text { Recurrence rate }\end{array}$ & $\begin{array}{c}\text { Not } \\
\text { conducted }\end{array}$ \\
\hline 7 & $\begin{array}{l}\text { Mant et al., } \\
\text { (2017) }\end{array}$ & UK & Colorectal & $\begin{array}{l}\text { CT and } \\
\text { CEA } \\
\text { follow-up }\end{array}$ & $\begin{array}{l}\text { Minimal } \\
\text { follow-up }\end{array}$ & CUA & $\begin{array}{l}\text { Randomized con- } \\
\text { trolled trial } \\
\text { and a pre-trial } \\
\text { economic model }\end{array}$ & $\begin{array}{l}\text { Costs and } \\
\text { benefits } \\
3.5 \%\end{array}$ & $\begin{array}{l}\text { The } \\
\text { perspective of } \\
\text { the UK NHS }\end{array}$ & $\begin{array}{l}\text { Costs for visits } \\
\text { and tests }\end{array}$ & 8 years & $\Delta$ cost $/ \Delta \mathrm{QALY}$ & SA, TA \\
\hline 8 & $\begin{array}{c}\text { Grogan } \\
\text { et al., (2002) }\end{array}$ & Australia & Breast & $\begin{array}{l}13 \\
\text { follow-up } \\
\text { schedules }\end{array}$ & $\begin{array}{l}\text { Minimal } \\
\text { follow-up }\end{array}$ & $\begin{array}{l}\text { Costing } \\
\text { study }\end{array}$ & $\begin{array}{l}\text { Retrospective } \\
\text { data audit } \\
\text { used to estab- } \\
\text { lish an em- } \\
\text { pirical model }\end{array}$ & NA & $\begin{array}{l}\text { Not reported } \\
\text { (health } \\
\text { system) }\end{array}$ & $\begin{array}{l}\text { Costs for visits } \\
\text { and tests }\end{array}$ & 70 months & $\begin{array}{l}\text { Cost of follow-up } \\
\text { per detection of } \\
\text { salvageable event } \\
\text { per patient }\end{array}$ & $\begin{array}{c}\text { Not } \\
\text { conducted }\end{array}$ \\
\hline 9 & $\begin{array}{l}\text { Kokko et al., } \\
\quad(2005)\end{array}$ & Finland & Breast & $\begin{array}{l}\text { Routine } \\
\text { follow-up }\end{array}$ & Unclear & $\begin{array}{l}\text { Costing } \\
\text { study }\end{array}$ & $\begin{array}{l}\text { Randomized } \\
\text { controlled } \\
\text { trial }\end{array}$ & No & $\begin{array}{l}\text { The hospital } \\
\text { perspective }\end{array}$ & $\begin{array}{l}\text { Costs for visits } \\
\text { and tests }\end{array}$ & 4 years & $\begin{array}{l}\text { Cost of follow-up } \\
\text { per patient } \\
\text { Cost per detected } \\
\text { recurrence }\end{array}$ & $\begin{array}{c}\text { Not } \\
\text { conducted }\end{array}$ \\
\hline
\end{tabular}


Table A5. Cont.

\begin{tabular}{|c|c|c|c|c|c|c|c|c|c|c|c|c|c|}
\hline & $\begin{array}{c}\text { Author } \\
\text { (Publica- } \\
\text { tion Year) }\end{array}$ & Setting & $\begin{array}{l}\text { Type of } \\
\text { Cancer }\end{array}$ & Intervention & Comparator & EE Type & $\begin{array}{l}\text { Study } \\
\text { Design }\end{array}$ & $\begin{array}{l}\text { Discount } \\
\text { Rate }\end{array}$ & Perspective & Costs Included & $\begin{array}{l}\text { Time Horizon } \\
\text { Study Period }\end{array}$ & $\begin{array}{l}\text { Outcome } \\
\text { Measures }\end{array}$ & $\begin{array}{c}\text { Sensitivity } \\
\text { Analysis }\end{array}$ \\
\hline 10 & $\begin{array}{l}\text { Robertson } \\
\text { et al., (2011) }\end{array}$ & UK & Breast & Mammography & $\begin{array}{c}\text { No } \\
\text { yurveillance }\end{array}$ & CUA & $\begin{array}{l}\text { Markov } \\
\text { modeling }\end{array}$ & $\begin{array}{c}\text { Costs and } \\
\text { benefits } \\
3.5 \%\end{array}$ & The UK NHS & $\begin{array}{l}\text { Costs incurred } \\
\text { by the NHS }\end{array}$ & Lifetime & $\Delta \operatorname{cost} / \Delta \mathrm{QALY}$ & $\begin{array}{c}\text { OW, MW, } \\
\text { TA }\end{array}$ \\
\hline 11 & $\begin{array}{l}\text { Lu et al., } \\
\text { (2012) }\end{array}$ & $\begin{array}{l}\text { The Nether- } \\
\text { lands }\end{array}$ & Breast & $\begin{array}{l}3 \text { alternate } \\
\text { strategies }\end{array}$ & $\begin{array}{l}\text { Guideline } \\
\text { follow-up }\end{array}$ & CEA & $\begin{array}{l}\text { An extended } \\
\text { and validated } \\
\text { simulation } \\
\text { model }\end{array}$ & NA & $\begin{array}{l}\text { Not reported } \\
\text { (health } \\
\text { system) }\end{array}$ & $\begin{array}{c}\text { Costs for } \\
\text { follow-up tests } \\
\text { Percentage of } \\
\text { small tumors } \\
\text { identified by tests }\end{array}$ & Lifetime & $\begin{array}{l}\text { Detection rate of } \\
\text { small tumors } \\
(2 \mathrm{~cm} \text { or smaller }) \\
\text { and associated } \\
\text { costs for each } \\
\text { strategy } \\
\text { Additional costs } \\
\text { associated with an } \\
\text { increase of } 1 \% \text { in } \\
\text { the number } \\
\text { of early breast } \\
\text { cancers detected }\end{array}$ & $\begin{array}{c}\text { Not } \\
\text { conducted }\end{array}$ \\
\hline 12 & $\begin{array}{l}\text { Bessen et al., } \\
\text { (2015) }\end{array}$ & Australia & Breast & $\begin{array}{l}\text { Intensive } \\
\text { follow-up }\end{array}$ & $\begin{array}{l}\text { Simplified } \\
\text { follow-up }\end{array}$ & CUA & $\begin{array}{l}\text { Retrospective } \\
\text { data audit } \\
\text { and discrete } \\
\text { event simula- } \\
\text { tion model }\end{array}$ & NA & $\begin{array}{l}\text { Not reported } \\
\text { (health } \\
\text { system) }\end{array}$ & Costs for tests & 5 years & $\begin{array}{l}\text { Cost per QALY } \\
\text { gained; } \\
\Delta \text { cost } / \triangle \mathrm{QALY}\end{array}$ & SA, PSA \\
\hline 13 & $\begin{array}{l}\text { Draeger } \\
\text { et al., (2020) }\end{array}$ & $\begin{array}{l}\text { The Nether- } \\
\text { lands }\end{array}$ & Breast & Unclear & Unclear & CEA & $\begin{array}{l}\text { Quasi- } \\
\text { experimental } \\
\text { pre/post } \\
\text { study }\end{array}$ & NA & $\begin{array}{l}\text { Not reported } \\
\text { (health } \\
\text { system) }\end{array}$ & $\begin{array}{c}\text { Costs for } \\
\text { diagnostic } \\
\text { procedures, } \\
\text { clinical } \\
\text { follow-up visits }\end{array}$ & 5 years & $\begin{array}{l}\text { Potential savings } \\
\text { of follow-up }\end{array}$ & $\begin{array}{c}\text { Predefined } \\
\text { follow-up } \\
\text { sensitivity } \\
\text { analysis }\end{array}$ \\
\hline 14 & $\begin{array}{l}\text { Hengge } \\
\text { et al., (2007) }\end{array}$ & Germany & Melanoma & $\begin{array}{l}\text { Intensive } \\
\text { follow-up }\end{array}$ & $\begin{array}{l}\text { Guideline } \\
\text { follow-up }\end{array}$ & CUA & $\begin{array}{c}\text { Markov } \\
\text { model }\end{array}$ & NA & $\begin{array}{l}\text { Not reported } \\
\text { (health } \\
\text { system) }\end{array}$ & $\begin{array}{l}\text { Actual costs for } \\
\text { materials, scans, } \\
\text { human } \\
\text { resources and } \\
\text { overhead costs }\end{array}$ & 5 years & $\begin{array}{l}\text { Costs per detected } \\
\text { metastasis and } \\
\text { cost per QALY } \\
\text { gained }\end{array}$ & $\begin{array}{c}\text { Not } \\
\text { conducted }\end{array}$ \\
\hline 15 & $\begin{array}{l}\text { Leiter et al., } \\
\text { (2009) }\end{array}$ & Germany & Melanoma & Technical & None & CEA & $\begin{array}{l}\text { Retrospective } \\
\text { data audit }\end{array}$ & NA & $\begin{array}{l}\text { Not reported } \\
\text { (health } \\
\text { system) }\end{array}$ & $\begin{array}{l}\text { Cost for each } \\
\text { technical } \\
\text { follow-up } \\
\text { investigation }\end{array}$ & 5 years & $\begin{array}{l}\text { Costs for the } \\
\text { detection of one } \\
\text { recurrence }\end{array}$ & $\begin{array}{c}\text { Not } \\
\text { conducted }\end{array}$ \\
\hline 16 & $\begin{array}{l}\text { Podlipnik } \\
\text { et al., (2019) }\end{array}$ & Spain & $\begin{array}{l}\text { Malignant } \\
\text { melanoma }\end{array}$ & $\mathrm{CT}$ & $\begin{array}{l}\text { Contrast } \\
\text { brain MRI }\end{array}$ & CEA & $\begin{array}{l}\text { Decision } \\
\text { tree }\end{array}$ & Not applied & $\begin{array}{l}\text { Healthcare } \\
\text { system }\end{array}$ & $\begin{array}{l}\text { Costs for visits } \\
\text { and tests }\end{array}$ & 5 years & $\begin{array}{l}\text { Cost-effectiveness } \\
\text { ratio per patient }\end{array}$ & OW, SA \\
\hline 17 & $\begin{array}{l}\text { Forni et al., } \\
\text { (2007) }\end{array}$ & Italy & Cervical & $\begin{array}{l}\text { Simplified } \\
\text { follow-up }\end{array}$ & $\begin{array}{l}\text { Usual } \\
\text { follow-up }\end{array}$ & CEA & $\begin{array}{l}\text { Retrospective } \\
\text { data audit }\end{array}$ & NA & $\begin{array}{l}\text { Not reported } \\
\text { (health } \\
\text { system) }\end{array}$ & $\begin{array}{l}\text { The costs of the } \\
\text { examination } \\
\text { carried out }\end{array}$ & 5 years & $\begin{array}{l}\text { The number of } \\
\text { recurrences, cost } \\
\text { of per recurrence } \\
\text { per patient }\end{array}$ & $\begin{array}{c}\text { Not } \\
\text { conducted }\end{array}$ \\
\hline
\end{tabular}


Table A5. Cont.

\begin{tabular}{|c|c|c|c|c|c|c|c|c|c|c|c|c|c|}
\hline & $\begin{array}{c}\text { Author } \\
\text { (Publica- } \\
\text { tion Year) }\end{array}$ & Setting & $\begin{array}{l}\text { Type of } \\
\text { Cancer }\end{array}$ & Intervention & Comparator & EE Type & $\begin{array}{l}\text { Study } \\
\text { Design }\end{array}$ & $\begin{array}{l}\text { Discount } \\
\text { Rate }\end{array}$ & Perspective & Costs Included & $\begin{array}{l}\text { Time Horizon } \\
\text { Study Period }\end{array}$ & $\begin{array}{l}\text { Outcome } \\
\text { Measures }\end{array}$ & $\begin{array}{c}\text { Sensitivity } \\
\text { Analysis }\end{array}$ \\
\hline 18 & $\begin{array}{l}\text { Baena- } \\
\text { Cañada } \\
\text { et al., (2013) }\end{array}$ & UK & Cervical & $\begin{array}{l}\text { Primary } \\
\text { care } \\
\text { follow-up }\end{array}$ & $\begin{array}{l}\text { Specialist- } \\
\text { led } \\
\text { follow-up }\end{array}$ & CMA & $\begin{array}{l}\text { Retrospective } \\
\text { data audit }\end{array}$ & NA & $\begin{array}{l}\text { Not reported } \\
\text { (health } \\
\text { system) }\end{array}$ & $\begin{array}{l}\text { Costs for visits } \\
\text { and } \\
\text { complementary } \\
\text { tests }\end{array}$ & 5 years & $\begin{array}{l}\text { Cost of the } \\
\text { follow-up, events, } \\
\text { HRQL and } \\
\text { satisfaction }\end{array}$ & $\begin{array}{c}\text { Not } \\
\text { conducted }\end{array}$ \\
\hline 19 & $\begin{array}{l}\text { Auguste } \\
\text { et al., (2014) }\end{array}$ & UK & Cervical & $\begin{array}{l}\text { MRI with or } \\
\text { without CT }\end{array}$ & $\begin{array}{l}\text { Clinical } \\
\text { follow-up }\end{array}$ & CUA & $\begin{array}{c}\text { Markov } \\
\text { model }\end{array}$ & Costs $3.5 \%$ & $\begin{array}{l}\text { Healthcare } \\
\text { system }\end{array}$ & Costs for tests & 5 years & $\Delta \operatorname{cost} / \Delta \mathrm{QALY}$ & $\begin{array}{c}\text { OW, SA, } \\
\text { PSA }\end{array}$ \\
\hline 20 & $\begin{array}{l}\text { Shah et al., } \\
\text { (2015) }\end{array}$ & Australia & $\begin{array}{c}\text { Head, neck } \\
\text { + nasopha- } \\
\text { ryngeal }\end{array}$ & $\begin{array}{l}\text { PET-CT } \\
\text { scan }\end{array}$ & $\begin{array}{l}\text { No PET-CT } \\
\text { scan }\end{array}$ & CEA & $\begin{array}{l}\text { Quasi- } \\
\text { experimental } \\
\text { pre/post } \\
\text { study }\end{array}$ & Costs $5 \%$ & $\begin{array}{c}\text { Hospital } \\
\text { perspective }\end{array}$ & Direct costs & 5 years & $\begin{array}{l}\text { Cost of follow-up } \\
\text { strategies } \\
\text { The proportion of } \\
\text { radically treatable } \\
\text { recurrences }\end{array}$ & $\begin{array}{c}\text { Not } \\
\text { conducted }\end{array}$ \\
\hline 21 & $\begin{array}{l}\text { Meregaglia } \\
\text { et al., (2018) }\end{array}$ & $\begin{array}{l}\text { Italy and } \\
\text { Switzerland }\end{array}$ & $\begin{array}{l}\text { Head and } \\
\text { neck }\end{array}$ & $\begin{array}{l}\text { Intensive } \\
\text { follow-up }\end{array}$ & $\begin{array}{l}\text { Symptom- } \\
\text { driven } \\
\text { surveillance }\end{array}$ & CUA & $\begin{array}{c}\text { Markov } \\
\text { model }\end{array}$ & $\begin{array}{c}\text { Costs and } \\
\text { benefits 3\% }\end{array}$ & $\begin{array}{l}\text { Healthcare } \\
\text { system }\end{array}$ & $\begin{array}{c}\text { Costs for } \\
\text { hospital } \\
\text { admissions, } \\
\text { specialist visits, } \\
\text { radiological } \\
\text { exams, } \\
\text { laboratory tests } \\
\text { and outpatient } \\
\text { treatment }\end{array}$ & Lifetime & $\begin{array}{c}\Delta \cos t / \Delta Q A L Y \\
\Delta \operatorname{cost} / \Delta \mathrm{LYG}\end{array}$ & $\begin{array}{c}\text { OW, TW, } \\
\text { PSA }\end{array}$ \\
\hline 22 & $\begin{array}{c}\text { Dryver } \\
\text { et al., (2003) }\end{array}$ & Canada & $\begin{array}{l}\text { Hodgkin's } \\
\text { disease }\end{array}$ & $\begin{array}{c}\text { CXR, CT, } \\
\text { blood count }\end{array}$ & None & $\begin{array}{l}\text { Costing } \\
\text { study }\end{array}$ & $\begin{array}{c}\text { Retrospective } \\
\text { data audit }\end{array}$ & NA & $\begin{array}{l}\text { Not reported } \\
\text { (health } \\
\text { system) }\end{array}$ & $\begin{array}{l}\text { Costs for visits } \\
\text { and tests }\end{array}$ & $\begin{array}{l}1-120 \\
\text { months }\end{array}$ & $\begin{array}{l}\text { the cost per true } \\
\text { relapse }\end{array}$ & $\begin{array}{c}\text { Not } \\
\text { conducted }\end{array}$ \\
\hline 23 & $\begin{array}{l}\text { Guadagnolo } \\
\text { et al., (2006) }\end{array}$ & USA & $\begin{array}{c}\text { Hodgkin's } \\
\text { disease }\end{array}$ & $\begin{array}{c}\text { Routine } \\
\text { annual CT }\end{array}$ & $\begin{array}{l}\text { Non-CT } \\
\text { modalities }\end{array}$ & CUA & $\begin{array}{c}\text { Markov } \\
\text { model }\end{array}$ & $\begin{array}{c}\text { Costs and } \\
\text { benefits 3\% }\end{array}$ & $\begin{array}{l}\text { Modified } \\
\text { societal } \\
\text { perspective }\end{array}$ & $\begin{array}{l}\text { Visits and blood } \\
\text { tests }\end{array}$ & Lifetime & $\begin{array}{l}\Delta \operatorname{cost} / \Delta \mathrm{QALY} \\
\text { and } \Delta \operatorname{cost} / \Delta \mathrm{LY}\end{array}$ & SA, OW \\
\hline 24 & $\begin{array}{l}\text { Clasen et al., } \\
\quad(2009)\end{array}$ & Germany & Seminoma & Technical & None & $\begin{array}{l}\text { Costing } \\
\text { study }\end{array}$ & $\begin{array}{l}\text { Retrospective } \\
\text { data audit }\end{array}$ & NA & $\begin{array}{c}\text { Not reported } \\
\text { (health } \\
\text { system) }\end{array}$ & $\begin{array}{l}\text { Cost for each } \\
\text { technical } \\
\text { follow-up } \\
\text { investigation }\end{array}$ & 10 years & $\begin{array}{l}\text { Cost per relapse } \\
\text { detected }\end{array}$ & $\begin{array}{c}\text { Not } \\
\text { conducted }\end{array}$ \\
\hline 25 & $\begin{array}{l}\text { Charytonowicz } \\
\text { et al., (2019) }\end{array}$ & USA & TGCT & $\begin{array}{l}\text { mRNA } \\
\text { testing }\end{array}$ & $\begin{array}{l}\text { CT-based } \\
\text { follow-up }\end{array}$ & $\begin{array}{l}\text { Costing } \\
\text { study }\end{array}$ & $\begin{array}{c}\text { Markov } \\
\text { model }\end{array}$ & $\begin{array}{c}\text { Costa and } \\
\text { benefits 5\% }\end{array}$ & $\begin{array}{l}\text { Healthcare } \\
\text { system }\end{array}$ & $\begin{array}{l}\text { Costs for visits } \\
\text { and tests }\end{array}$ & 10 years & $\begin{array}{c}\text { The sensitivity of } \\
\text { each tests } \\
\text { The cost of } \\
\text { follow-up care }\end{array}$ & OW \\
\hline 26 & $\begin{array}{c}\text { Gilbert } \\
\text { et al., (2000) }\end{array}$ & Canada & Lung & $\begin{array}{c}\text { Specialist } \\
\text { outpatient }\end{array}$ & $\begin{array}{c}\text { Non- } \\
\text { specialist } \\
\text { follow-up }\end{array}$ & CEA & $\begin{array}{l}\text { Retrospective } \\
\text { data audit }\end{array}$ & NA & $\begin{array}{l}\text { Not reported } \\
\text { (health } \\
\text { system) }\end{array}$ & $\begin{array}{c}\text { Personnel, } \\
\text { infrastructure } \\
\text { and test costs }\end{array}$ & $\begin{array}{l}1 \text { to } 107 \\
\text { months }\end{array}$ & $\begin{array}{c}\text { Cost per } \\
\text { recurrence } \\
\text { detected by a } \\
\text { surgeon or FP and } \\
5 \text { years survival } \\
\text { rate }\end{array}$ & $\begin{array}{c}\text { Not } \\
\text { conducted }\end{array}$ \\
\hline
\end{tabular}


Table A5. Cont.

\begin{tabular}{|c|c|c|c|c|c|c|c|c|c|c|c|c|c|}
\hline & $\begin{array}{l}\text { Author } \\
\text { (Publica- } \\
\text { tion Year) }\end{array}$ & Setting & $\begin{array}{l}\text { Type of } \\
\text { Cancer }\end{array}$ & Intervention & Comparator & EE Type & $\begin{array}{l}\text { Study } \\
\text { Design }\end{array}$ & $\begin{array}{l}\text { Discount } \\
\text { Rate }\end{array}$ & Perspective & Costs Included & $\begin{array}{l}\text { Time Horizon } \\
\text { Study Period }\end{array}$ & $\begin{array}{l}\text { Outcome } \\
\text { Measures }\end{array}$ & $\begin{array}{c}\text { Sensitivity } \\
\text { Analysis }\end{array}$ \\
\hline 27 & $\begin{array}{l}\text { Dion et al., } \\
\quad(2010)\end{array}$ & Canada & Renal & $\begin{array}{l}\text { Clinical } \\
\text { guidelines }\end{array}$ & $\begin{array}{l}\text { Usual } \\
\text { follow-up }\end{array}$ & CEA & $\begin{array}{l}\text { Retrospective } \\
\text { data audit }\end{array}$ & NA & $\begin{array}{l}\text { Not reported } \\
\text { (health } \\
\text { system) }\end{array}$ & $\begin{array}{l}\text { Costs for visits } \\
\text { and tests }\end{array}$ & 5 years & $\begin{array}{l}\text { The total cost of } \\
\text { follow-up per } \\
\text { patient and per } \\
\text { patient month } \\
\text { The cost per } \\
\text { recurrence }\end{array}$ & $\begin{array}{c}\text { Not } \\
\text { conducted }\end{array}$ \\
\hline 28 & $\begin{array}{l}\text { C. R. } \\
\text { Rettenmaier } \\
\text { et al., (2010) }\end{array}$ & USA & Uterine & Imaging & None & $\begin{array}{l}\text { Costing } \\
\text { study }\end{array}$ & $\begin{array}{l}\text { Retrospective } \\
\text { data audit }\end{array}$ & NA & $\begin{array}{l}\text { Not reported } \\
\text { (health } \\
\text { system) }\end{array}$ & $\begin{array}{l}\text { Costs for tests } \\
\text { and visits }\end{array}$ & 20 years & $\begin{array}{c}\text { The cost per } \\
\text { patient recurrence }\end{array}$ & $\begin{array}{c}\text { Not } \\
\text { conducted }\end{array}$ \\
\hline 29 & $\begin{array}{l}\mathrm{N} . \\
\text { Rettenmaier } \\
\text { et al., (2010) }\end{array}$ & USA & $\begin{array}{l}\text { Ovarian } \\
\text { and primary } \\
\text { peritoneal }\end{array}$ & Imaging & None & $\begin{array}{l}\text { Costing } \\
\text { study }\end{array}$ & $\begin{array}{l}\text { Retrospective } \\
\text { data audit }\end{array}$ & NA & $\begin{array}{l}\text { Not reported } \\
\text { (health } \\
\text { system) }\end{array}$ & $\begin{array}{l}\text { Costs for tests } \\
\text { and visits }\end{array}$ & 16 years & $\begin{array}{l}\text { The cost per } \\
\text { patient recurrence }\end{array}$ & $\begin{array}{c}\text { Not } \\
\text { conducted }\end{array}$ \\
\hline 30 & $\begin{array}{l}\text { Imran et al., } \\
\quad(2019)\end{array}$ & Canada & Thyroid & $\begin{array}{l}\text { Primary } \\
\text { care follow- } \\
\text { up }\end{array}$ & $\begin{array}{l}\text { Tertiary care } \\
\text { follow-up }\end{array}$ & CEA & $\begin{array}{l}\text { Retrospective } \\
\text { data audit }\end{array}$ & NA & Not reported & $\begin{array}{l}\text { Costs for visits } \\
\text { and tests } \\
\text { Travel costs }\end{array}$ & 62 months & $\begin{array}{l}\text { Cost of follow-up } \\
\text { care and travel } \\
\text { cost per patients } \\
\text { Rates of recur- } \\
\text { rence and cancer- } \\
\text { related mortality }\end{array}$ & $\begin{array}{c}\text { Not } \\
\text { conducted }\end{array}$ \\
\hline 31 & $\begin{array}{l}\text { Dansk et al., } \\
\text { (2016) }\end{array}$ & Sweden & Bladder & $\begin{array}{c}\text { Flexible } \\
\text { cystoscopy } \\
\text { with WLFC } \\
\text { and BLFC }\end{array}$ & $\begin{array}{c}\text { Flexible } \\
\text { cystoscopy } \\
\text { with WLFC } \\
\text { only }\end{array}$ & CCA & $\begin{array}{l}\text { Mixed: deci- } \\
\text { sion tree and } \\
\text { Markov } \\
\text { model }\end{array}$ & Costs $3 \%$ & $\begin{array}{l}\text { Hospital and } \\
\text { other } \\
\text { purchaser } \\
\text { perspectives }\end{array}$ & $\begin{array}{l}\text { Costs for visits } \\
\text { and tests }\end{array}$ & 5 years & $\begin{array}{l}\text { Cost of follow-up } \\
\text { strategy } \\
\text { Detection rate, } \\
\text { hospital bed days } \\
\text { and number of } \\
\text { procedures }\end{array}$ & SA \\
\hline 32 & $\begin{array}{l}\text { Pearce et al., } \\
\quad(2016)\end{array}$ & Ireland & Prostate & $\begin{array}{l}\text { Guideline } \\
\text { follow-up }\end{array}$ & $\begin{array}{l}\text { Current } \\
\text { guideline }\end{array}$ & CMA & $\begin{array}{c}\text { Markov } \\
\text { model }\end{array}$ & Costs $5 \%$ & $\begin{array}{l}\text { Healthcare } \\
\text { payer }\end{array}$ & Costs for visits & 10 years & $\begin{array}{l}\text { The average cost } \\
\text { of follow-up per } \\
\text { survivor }\end{array}$ & OW, PSA \\
\hline 33 & $\begin{array}{l}\text { Gao et al., } \\
\text { (2017) }\end{array}$ & Australia & $\begin{array}{l}\text { Hem. } \\
\text { malignancy }\end{array}$ & $\begin{array}{l}\text { 12-month } \\
\text { interven- } \\
\text { tion }\end{array}$ & None & CEA & $\begin{array}{c}\text { Markov } \\
\text { model }\end{array}$ & $\begin{array}{c}\text { Costs and } \\
\text { benefits 3\% }\end{array}$ & $\begin{array}{l}\text { Health sector } \\
\text { perspective }\end{array}$ & $\begin{array}{l}\text { Costs for } \\
\text { individual } \\
\text { fitness activities, } \\
\text { dietician time, } \\
\text { project man- } \\
\text { ager/physiotherapist } \\
\text { time }\end{array}$ & $\begin{array}{l}\text { Lifetime } \\
\text { ist }\end{array}$ & $\begin{array}{l}\Delta \text { cost } / \Delta \text { health- } \\
\text { adjusted life years } \\
\text { (HALYs) gained }\end{array}$ & OW, SA \\
\hline 34 & $\begin{array}{l}\text { Ehrhardt } \\
\text { et al., (2020) }\end{array}$ & USA & $\begin{array}{l}\text { Childhood } \\
\text { cancer }\end{array}$ & $\begin{array}{c}1-, 2-, 3-, 5- \\
\text { and 10-year } \\
\text { interval } \\
\text { screening }\end{array}$ & $\begin{array}{c}\text { No } \\
\text { screening }\end{array}$ & CUA & $\begin{array}{l}\text { Microsimulatio } \\
\text { model }\end{array}$ & $\begin{array}{l}\text { on Costs and } \\
\text { benefits 3\% }\end{array}$ & $\begin{array}{l}\text { Not reported } \\
\text { (societal } \\
\text { perspective) }\end{array}$ & $\begin{array}{l}\text { Medical costs } \\
\text { and indirect } \\
\text { patient costs, } \\
\text { such as lost } \\
\text { work time }\end{array}$ & Lifetime & $\Delta \cos t / \Delta \mathrm{QALY}$ & OW, TW \\
\hline
\end{tabular}

CUA—cost-utility analysis; CEA—cost-effectiveness analysis; CCA—cost-consequence analysis; CMA—cost minimization analysis; OW—on-
analysis; TA—-threshold analysis; MW—-multi-way; QALY - quality-adjusted life year; HALY—health-adjusted life year; LYG—life-year gained. 


\section{Appendix D}

Table A6. CHEERS checklist-items to include when reporting economic evaluation of health interventions.

\begin{tabular}{|c|c|c|}
\hline Number of ITEM & Description of ITEM & Summary of Criterion \\
\hline Item 1 & $\begin{array}{c}\text { Identify the study as an economic evaluation or use more specific } \\
\text { terms such as "cost-effectiveness analysis", and describe the } \\
\text { interventions compared. }\end{array}$ & Title identifies an economic evaluation \\
\hline Item 2 & $\begin{array}{c}\text { Provide a structured summary of objectives, perspective, setting, } \\
\text { methods (including study design and inputs), results (including } \\
\text { base case and uncertainty analyses) and conclusions. }\end{array}$ & $\begin{array}{l}\text { Structured summary was presented } \\
\text { in abstract }\end{array}$ \\
\hline Item 3 & $\begin{array}{l}\text { Provide an explicit statement of the broader context for the study. } \\
\text { Present the study question and its relevance for health policy or } \\
\text { practice decisions. }\end{array}$ & $\begin{array}{l}\text { Background and objectives } \\
\text { were provided }\end{array}$ \\
\hline Item 4 & $\begin{array}{l}\text { Describe characteristics of the base case population and } \\
\text { subgroups analyzed, including why they were chosen. }\end{array}$ & $\begin{array}{l}\text { Target population and subgroups } \\
\text { were reported }\end{array}$ \\
\hline Item 5 & $\begin{array}{l}\text { State relevant aspects of the system(s) in which the decision(s) } \\
\text { need(s) to be made. }\end{array}$ & Setting and location were reported \\
\hline Item 6 & $\begin{array}{c}\text { Describe the perspective of the study and relate this to the costs } \\
\text { being evaluated. }\end{array}$ & Study perspective was reported \\
\hline Item 7 & $\begin{array}{l}\text { Describe the interventions or strategies being compared and state } \\
\text { why they were chosen. }\end{array}$ & Comparator(s) was/were reported \\
\hline Item 8 & $\begin{array}{c}\text { State the time horizon(s) over which costs and consequences are } \\
\text { being evaluated and say why appropriate. }\end{array}$ & Time horizon was reported \\
\hline Item 9 & $\begin{array}{l}\text { Report the choice of discount rate(s) used for costs and outcomes } \\
\text { and say why appropriate. }\end{array}$ & Discount rate was used \\
\hline Item 10 & $\begin{array}{c}\text { Describe what outcomes were used as the measure(s) of benefit in } \\
\text { the evaluation and their relevance for the type of } \\
\text { analysis performed. }\end{array}$ & $\begin{array}{l}\text { Choice of health outcomes } \\
\text { was reported }\end{array}$ \\
\hline Item 11 & $\begin{array}{l}\text { a. Single study-based estimates: Describe fully the design features } \\
\text { of the single effectiveness study and why the single study was a } \\
\text { sufficient source of clinical effectiveness data. } \\
\text { b. Synthesis-based estimates: Describe fully the methods used for } \\
\text { identification of included studies and synthesis of clinical } \\
\text { effectiveness data. }\end{array}$ & $\begin{array}{l}\text { a. Measurement of effectiveness (single } \\
\text { study-based) } \\
\text { b. Measurement of effectiveness } \\
\text { (synthesis-based) was reported }\end{array}$ \\
\hline Item 12 & $\begin{array}{l}\text { If applicable, describe the population and methods used to elicit } \\
\text { preferences for outcomes. }\end{array}$ & $\begin{array}{l}\text { Measurement and valuation of } \\
\text { preference-based outcomes }\end{array}$ \\
\hline Item 13 & $\begin{array}{l}\text { a. Single study-based economic evaluation: Describe approaches } \\
\text { used to estimate resource use associated with the alternative } \\
\text { interventions. Describe primary or secondary research methods } \\
\text { for valuing each resource item in terms of its unit cost. Describe } \\
\text { any adjustments made to approximate to opportunity costs. } \\
\text { b. Model-based economic evaluation: Describe approaches and } \\
\text { data sources used to estimate resource use associated with model } \\
\text { health states. Describe primary or secondary research methods } \\
\text { for valuing each resource item in terms of its unit cost. Describe } \\
\text { any adjustments made to approximate to opportunity costs. }\end{array}$ & $\begin{array}{l}\text { a. Estimating resources and } \\
\text { costs-single study-based } \\
\text { b. Estimating resources and } \\
\text { costs-model-based }\end{array}$ \\
\hline Item 14 & $\begin{array}{l}\text { Report the dates of the estimated resource quantities and unit } \\
\text { costs. Describe methods for adjusting estimated unit costs to the } \\
\text { year of reported costs if necessary. Describe methods for convert- } \\
\text { ing costs into a common currency base and the exchange rate. } \\
\text { Describe and give reasons for the specific type of }\end{array}$ & $\begin{array}{l}\text { Currency, price date and conversion } \\
\text { were reported }\end{array}$ \\
\hline Item 15 & $\begin{array}{l}\text { decision-analytical model used. Providing a figure to show model } \\
\text { structure is strongly recommended. }\end{array}$ & Choice of model was reported \\
\hline
\end{tabular}


Table A6. Cont.

\begin{tabular}{|c|c|c|}
\hline Number of ITEM & Description of ITEM & Summary of Criterion \\
\hline Item 16 & $\begin{array}{l}\text { Describe all structural or other assumptions underpinning the } \\
\text { decision-analytical model. }\end{array}$ & Assumptions were described \\
\hline Item 17 & $\begin{array}{l}\text { Describe all analytical methods supporting the evaluation. This } \\
\text { could include methods for dealing with skewed, missing, or } \\
\text { censored data; extrapolation methods; methods for pooling data; } \\
\text { approaches to validate or make adjustments (such as half cycle } \\
\text { corrections) to a model; and methods for handling population } \\
\text { heterogeneity and uncertainty. }\end{array}$ & Analytic methods were described \\
\hline Item 18 & $\begin{array}{l}\text { Report the values, ranges, references and, if used, probability } \\
\text { distributions for all parameters. Report reasons or sources for } \\
\text { distributions used to represent uncertainty where appropriate. } \\
\text { Providing a table to show the input values is } \\
\text { strongly recommended. }\end{array}$ & Study parameters were reported \\
\hline Item 19 & $\begin{array}{c}\text { For each intervention, report mean values for the main categories } \\
\text { of estimated costs and outcomes of interest, as well as mean } \\
\text { differences between the comparator groups. If applicable, report } \\
\text { incremental cost-effectiveness ratios. }\end{array}$ & $\begin{array}{l}\text { Incremental cost and outcomes } \\
\text { were reported }\end{array}$ \\
\hline Item 20 & $\begin{array}{l}\text { a. Single study-based economic evaluation: Describe the effects of } \\
\text { sampling uncertainty for the estimated incremental cost and } \\
\text { incremental effectiveness parameters, together with the impact of } \\
\text { methodological assumptions (such as } \\
\text { discount rate, study perspective). } \\
\text { b. Model-based economic evaluation: Describe the effects on the } \\
\text { results of uncertainty for all input parameters, and uncertainty } \\
\text { related to the structure of the model and assumptions. }\end{array}$ & $\begin{array}{l}\text { a. Characterizing uncertainty (single } \\
\text { study-based) } \\
\text { b. Characterizing uncertainty } \\
\text { (model-based) was reported }\end{array}$ \\
\hline Item 21 & $\begin{array}{c}\text { If applicable, report differences in costs, outcomes, or } \\
\text { cost-effectiveness that can be explained by variations between } \\
\text { subgroups of patients with different baseline characteristics or } \\
\text { other observed variability in effects that are not reducible by } \\
\text { more information. }\end{array}$ & $\begin{array}{l}\text { Characterizing heterogeneity } \\
\text { was reported }\end{array}$ \\
\hline Item 22 & $\begin{array}{l}\text { Summarize key study findings and describe how they support the } \\
\text { conclusions reached. Discuss limitations and the generalizability } \\
\text { of the findings and how the findings fit with current knowledge. } \\
\text { Describe how the study was funded and the role of the funder in }\end{array}$ & $\begin{array}{l}\text { Study findings, limitations, } \\
\text { generalizability and current knowledge } \\
\text { were mentioned }\end{array}$ \\
\hline Item 23 & $\begin{array}{l}\text { the identification, design, conduct, and reporting of the analysis. } \\
\text { Describe other nonmonetary sources of support. }\end{array}$ & Source of funding was mentioned \\
\hline Item 24 & $\begin{array}{l}\text { Describe any potential for conflict of interest of study contributors } \\
\text { in accordance with journal policy. In the absence of a journal } \\
\text { policy, we recommend authors comply with International } \\
\text { Committee of Medical Journal Editors recommendations. }\end{array}$ & Conflicts of interest were presented \\
\hline
\end{tabular}

The reporting quality of the selected papers was assessed using the Consolidated Health Economic Evaluation Reporting Standards (CHEERS), consisting of a 24-item checklist with accompanying recommendations to ensure consistent and transparent reporting in economic evaluations [16]. 
Table A7. Quality of reporting assessment using the CHEERS criteria.

\begin{tabular}{|c|c|c|c|c|c|c|c|c|c|c|c|c|c|c|c|c|c|c|c|c|c|c|c|c|c|}
\hline & & $\begin{array}{c}\text { Item } \\
1\end{array}$ & $\begin{array}{c}\text { Item } \\
2 \\
\end{array}$ & $\begin{array}{c}\text { Item } \\
3 \\
\end{array}$ & $\begin{array}{c}\text { Item } \\
4\end{array}$ & $\begin{array}{c}\text { Item } \\
5\end{array}$ & $\begin{array}{c}\text { Item } \\
6\end{array}$ & $\begin{array}{c}\text { Item } \\
7 \\
\end{array}$ & $\begin{array}{c}\text { Item } \\
8 \\
\end{array}$ & $\begin{array}{c}\text { Item } \\
9\end{array}$ & $\begin{array}{c}\text { Item } \\
10\end{array}$ & $\begin{array}{c}\text { Item } \\
11\end{array}$ & $\begin{array}{c}\text { Item } \\
12\end{array}$ & $\begin{array}{c}\text { Item } \\
13\end{array}$ & $\begin{array}{c}\text { Item } \\
14\end{array}$ & $\begin{array}{c}\text { Item } \\
15\end{array}$ & $\begin{array}{c}\text { Item } \\
16\end{array}$ & $\begin{array}{c}\text { Item } \\
17\end{array}$ & $\begin{array}{c}\text { Item } \\
18\end{array}$ & $\begin{array}{c}\text { Item } \\
19\end{array}$ & $\begin{array}{c}\text { Item } \\
20\end{array}$ & $\begin{array}{c}\text { Item } \\
21\end{array}$ & $\begin{array}{c}\text { Item } \\
22\end{array}$ & $\begin{array}{c}\text { Item } \\
23\end{array}$ & $\begin{array}{c}\text { Item } \\
24\end{array}$ \\
\hline 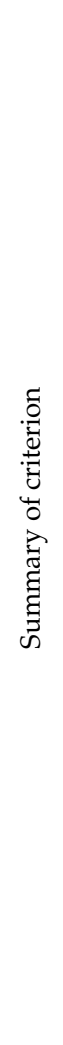 & 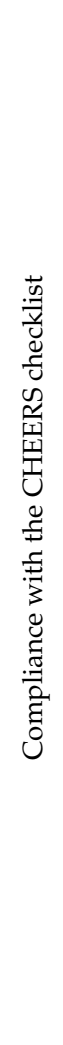 & 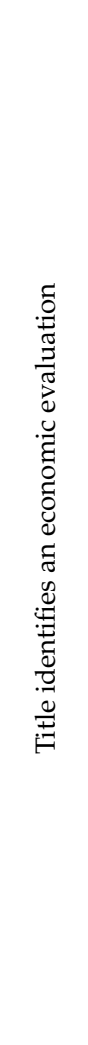 & 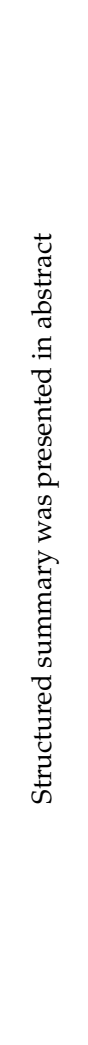 & 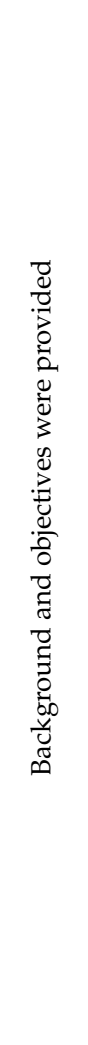 & 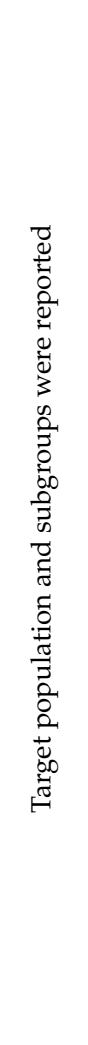 & 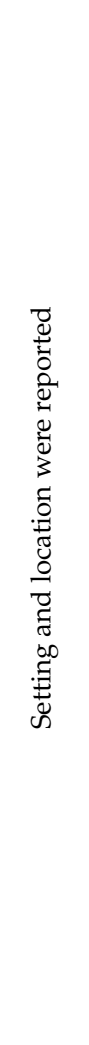 & 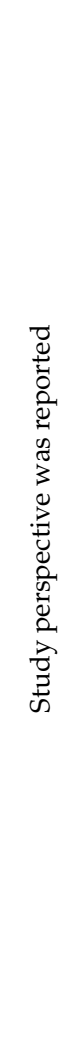 & 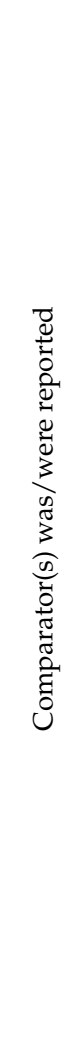 & 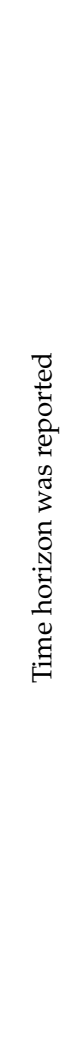 & 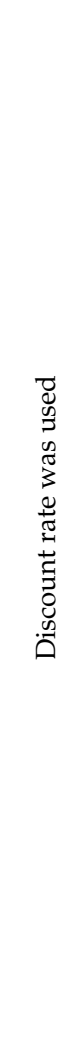 & 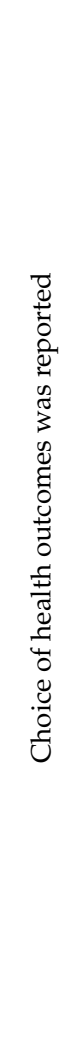 & 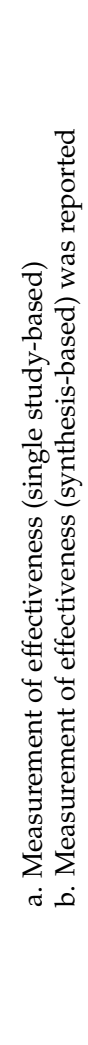 & 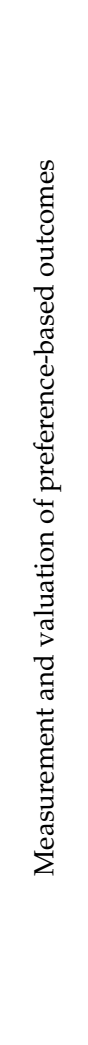 & 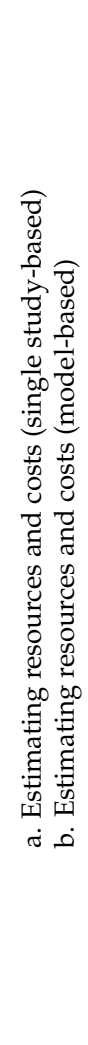 & 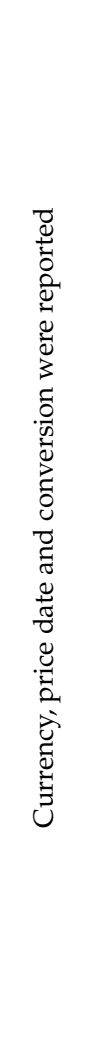 & 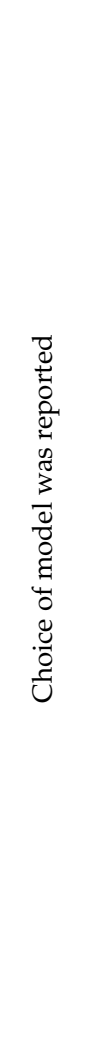 & 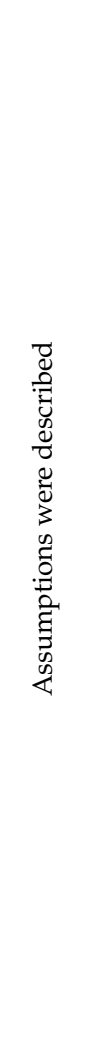 & 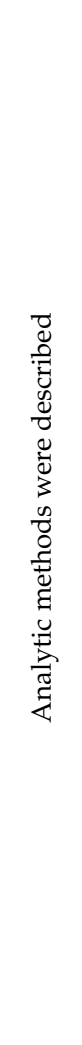 & 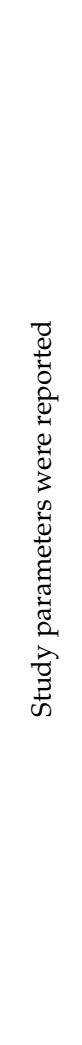 & 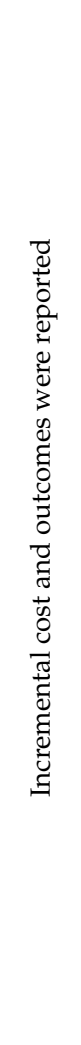 & 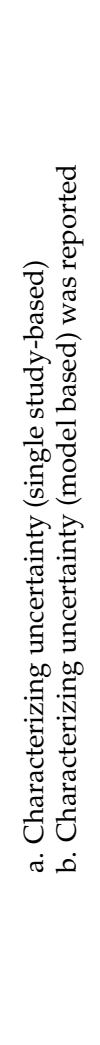 & 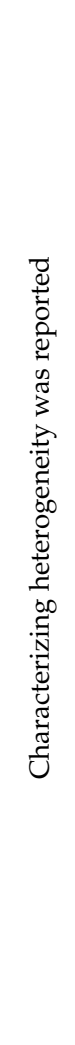 & 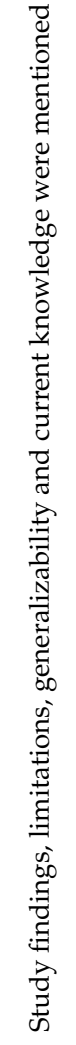 & 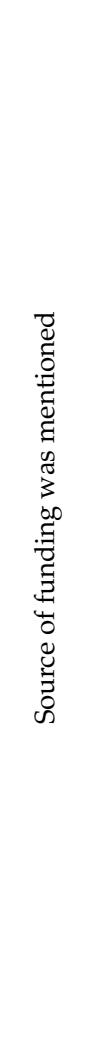 & 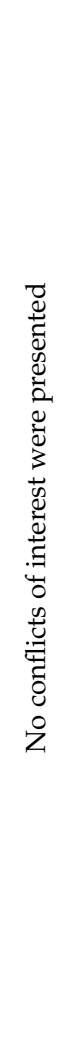 \\
\hline
\end{tabular}

Colorectal cancer

\begin{tabular}{|c|c|c|c|c|c|c|c|c|c|c|c|c|c|c|c|c|c|c|c|c|c|c|c|c|c|c|}
\hline 1 & $\begin{array}{l}\text { Staib et al., } \\
(2000)\end{array}$ & $50 \%$ & 1 & $0.5^{b}$ & 1 & 1 & 1 & 0 & 0 & 1 & NA & 1 & 1 & NA & 1 & 1 & NA & NA & NA & 0 & 0 & 0 & 0 & $0.5^{\mathrm{i}}$ & 0 & 0 \\
\hline 2 & $\begin{array}{l}\text { Bleeker } \\
\text { et al., } \\
(2001)\end{array}$ & $48 \%$ & $0.5^{\mathrm{a}}$ & $0.5^{b}$ & 1 & 1 & 1 & 0 & 0 & $0.5^{c}$ & NA & 1 & $0.5^{\mathrm{e}}$ & NA & 1 & 1 & NA & NA & NA & 0 & 0 & 0 & 0 & $0.5^{\mathrm{i}}$ & 1 & 0 \\
\hline 3 & $\begin{array}{l}\text { Borie et al., } \\
\quad(2004)\end{array}$ & $65 \%$ & 1 & $0.5^{b}$ & 1 & 1 & 1 & 0 & $0.5^{c}$ & 1 & 0 & 1 & $0.5^{\mathrm{e}}$ & 1 & 1 & 1 & 1 & 0 & 1 & 0 & 1 & 0 & 1 & 1 & 0 & 0 \\
\hline
\end{tabular}


Table A7. Cont.

\begin{tabular}{|c|c|c|c|c|c|c|c|c|c|c|c|c|c|c|c|c|c|c|c|c|c|c|c|c|c|c|}
\hline & & & $\begin{array}{c}\text { Item } \\
1\end{array}$ & $\begin{array}{l}\text { Item } \\
2\end{array}$ & $\begin{array}{c}\text { Item } \\
3\end{array}$ & $\begin{array}{c}\text { Item } \\
4\end{array}$ & $\begin{array}{l}\text { Item } \\
5\end{array}$ & $\begin{array}{c}\text { Item } \\
6\end{array}$ & $\begin{array}{c}\text { Item } \\
7\end{array}$ & $\begin{array}{c}\text { Item } \\
8\end{array}$ & $\begin{array}{l}\text { Item } \\
9\end{array}$ & $\begin{array}{c}\text { Item } \\
10\end{array}$ & $\begin{array}{c}\text { Item } \\
11\end{array}$ & $\begin{array}{c}\text { Item } \\
12\end{array}$ & $\begin{array}{c}\text { Item } \\
13\end{array}$ & $\begin{array}{c}\text { Item } \\
14\end{array}$ & $\begin{array}{c}\text { Item } \\
15\end{array}$ & $\begin{array}{c}\text { Item } \\
16\end{array}$ & $\begin{array}{c}\text { Item } \\
17\end{array}$ & $\begin{array}{c}\text { Item } \\
18\end{array}$ & $\begin{array}{c}\text { Item } \\
19\end{array}$ & $\begin{array}{l}\text { Item } \\
20\end{array}$ & $\begin{array}{c}\text { Item } \\
21\end{array}$ & $\begin{array}{c}\text { Item } \\
22\end{array}$ & $\begin{array}{l}\text { Item } \\
23\end{array}$ & $\begin{array}{l}\text { Item } \\
24\end{array}$ \\
\hline 4 & $\begin{array}{c}\text { Renehan } \\
\text { et al., } \\
\text { (2004) }\end{array}$ & $83 \%$ & 1 & 1 & 1 & 1 & 1 & 1 & 1 & 1 & $0.5^{c}$ & 1 & $0.5^{\mathrm{e}}$ & NA & 1 & 1 & 1 & 1 & 1 & 0 & 1 & 0 & 0 & 1 & 1 & 1 \\
\hline 5 & $\begin{array}{c}\text { Macafee } \\
\text { et al., } \\
\text { (2008) }\end{array}$ & $63 \%$ & 1 & $0.5^{\mathrm{b}}$ & 1 & 1 & 1 & 1 & 1 & $0.5^{c}$ & $0.5^{c}$ & 1 & $0.5^{\mathrm{e}}$ & NA & 1 & 1 & 0 & 1 & 0 & 0 & 0 & 0 & 1 & 1 & 0 & 1 \\
\hline 6 & $\begin{array}{c}\mathrm{Di} \\
\text { Cristofaro } \\
\text { et al., } \\
(2012) \\
\end{array}$ & $60 \%$ & 1 & $0.5^{\mathrm{b}}$ & 1 & 1 & 1 & 0 & 0 & $0.5^{c}$ & NA & 1 & $0.5^{\mathrm{e}}$ & NA & 1 & 1 & NA & NA & NA & 1 & 0 & 1 & 1 & $0.5^{\mathrm{i}}$ & 0 & 0 \\
\hline 7 & $\begin{array}{l}\text { Mant et al., } \\
\text { (2017) }\end{array}$ & $85 \%$ & 1 & $0.5^{\mathrm{b}}$ & 1 & 1 & 1 & 1 & 1 & 1 & $0.5^{c}$ & 1 & $0.5^{\mathrm{e}}$ & 1 & 1 & 1 & $0.5^{\mathrm{f}}$ & 1 & 1 & 1 & 1 & $0.5^{\mathrm{h}}$ & 0 & 1 & 1 & 1 \\
\hline \multicolumn{27}{|c|}{ Breast cancer } \\
\hline 8 & $\begin{array}{l}\text { Grogan } \\
\text { et al., } \\
\text { (2002) }\end{array}$ & $46 \%$ & $0.5^{\mathrm{a}}$ & $0.5^{\mathrm{b}}$ & 1 & 1 & 1 & 0 & 1 & $0.5^{c}$ & 0 & 1 & $0.5^{\mathrm{e}}$ & NA & 1 & 1 & $0.5^{\mathrm{f}}$ & 0 & 0 & 0 & 0 & 0 & 0 & $0.5^{\mathrm{i}}$ & 1 & 0 \\
\hline 9 & $\begin{array}{l}\text { Kokko } \\
\text { et al., } \\
(2005)\end{array}$ & $60 \%$ & $0.5^{\mathrm{a}}$ & $0.5^{\mathrm{b}}$ & 1 & 1 & 1 & 1 & 1 & $0.5^{c}$ & NA & 1 & $0.5^{\mathrm{e}}$ & NA & 1 & 1 & NA & NA & NA & 0 & 0 & 0 & 0 & 1 & 1 & 0 \\
\hline 10 & $\begin{array}{c}\text { Robertson } \\
\text { et al., } \\
\text { (2011) }\end{array}$ & $92 \%$ & 1 & $0.5^{\mathrm{b}}$ & 1 & 1 & 1 & 1 & 1 & $0.5^{c}$ & 1 & 1 & 1 & 1 & 1 & 1 & 1 & 1 & 1 & 1 & 1 & 0 & 1 & 1 & 1 & 1 \\
\hline 11 & $\begin{array}{l}\text { Lu et al., } \\
\text { (2012) }\end{array}$ & $65 \%$ & 1 & $0.5^{\mathrm{b}}$ & 1 & 1 & 1 & 0 & 1 & 1 & 0 & 1 & $0.5^{\mathrm{e}}$ & NA & 1 & 1 & 1 & 0 & $0.5^{g}$ & 1 & 0 & 1 & 0 & 1 & 0 & 1 \\
\hline 12 & $\begin{array}{l}\text { Bessen } \\
\text { et al., } \\
\text { (2015) }\end{array}$ & $71 \%$ & 1 & $0.5^{\mathrm{b}}$ & 1 & 1 & 1 & 0 & 1 & $0.5^{c}$ & 0 & 1 & $0.5^{\mathrm{e}}$ & NA & 1 & 1 & 1 & 1 & 1 & 1 & 0 & 1 & 1 & 1 & 1 & 0 \\
\hline 13 & $\begin{array}{c}\text { Draeger } \\
\text { et al., } \\
(2020) \\
\end{array}$ & $68 \%$ & $0.5^{\mathrm{a}}$ & $0.5^{\mathrm{b}}$ & 1 & 1 & 1 & 0 & 1 & 1 & NA & 1 & $0.5^{\mathrm{e}}$ & NA & 1 & 1 & NA & NA & NA & 0 & 1 & 0 & 0 & 1 & 1 & 1 \\
\hline \multicolumn{27}{|c|}{ Skin cancer } \\
\hline 14 & $\begin{array}{c}\text { Hengge } \\
\text { et al., } \\
\text { (2007) }\end{array}$ & $52 \%$ & 1 & $0.5^{\mathrm{b}}$ & 1 & 1 & 1 & 0 & 1 & $0.5^{c}$ & 0 & 1 & $0.5^{\mathrm{e}}$ & NA & 1 & 1 & 1 & 0 & 0 & 0 & 0 & 0 & 1 & 0 & 0 & 1 \\
\hline
\end{tabular}


Table A7. Cont.

\begin{tabular}{|c|c|c|c|c|c|c|c|c|c|c|c|c|c|c|c|c|c|c|c|c|c|c|c|c|c|c|}
\hline & & & $\begin{array}{c}\text { Item } \\
1\end{array}$ & $\begin{array}{c}\text { Item } \\
2 \\
\end{array}$ & $\begin{array}{c}\text { Item } \\
3 \\
\end{array}$ & $\begin{array}{c}\text { Item } \\
4\end{array}$ & $\begin{array}{c}\text { Item } \\
5 \\
\end{array}$ & $\begin{array}{c}\text { Item } \\
6\end{array}$ & $\begin{array}{c}\text { Item } \\
7\end{array}$ & $\begin{array}{c}\text { Item } \\
8\end{array}$ & $\begin{array}{c}\text { Item } \\
9\end{array}$ & $\begin{array}{c}\text { Item } \\
10\end{array}$ & $\begin{array}{c}\text { Item } \\
11\end{array}$ & $\begin{array}{c}\text { Item } \\
12\end{array}$ & $\begin{array}{c}\text { Item } \\
13\end{array}$ & $\begin{array}{c}\text { Item } \\
14\end{array}$ & $\begin{array}{c}\text { Item } \\
15\end{array}$ & $\begin{array}{c}\text { Item } \\
16\end{array}$ & $\begin{array}{c}\text { Item } \\
17\end{array}$ & $\begin{array}{c}\text { Item } \\
18\end{array}$ & $\begin{array}{c}\text { Item } \\
19\end{array}$ & $\begin{array}{c}\text { Item } \\
20\end{array}$ & $\begin{array}{c}\text { Item } \\
21\end{array}$ & $\begin{array}{c}\text { Item } \\
22\end{array}$ & $\begin{array}{c}\text { Item } \\
23\end{array}$ & $\begin{array}{c}\text { Item } \\
24\end{array}$ \\
\hline 15 & $\begin{array}{l}\text { Leiter } \\
\text { et al., } \\
\text { (2009) }\end{array}$ & $58 \%$ & $0.5^{\mathrm{a}}$ & $0.5^{b}$ & 1 & 1 & 1 & 0 & 0 & 1 & NA & 1 & $0.5^{\mathrm{e}}$ & NA & 1 & 1 & NA & NA & NA & 0 & 0 & 1 & 1 & 0 & 1 & 0 \\
\hline 16 & $\begin{array}{c}\text { Podlipnik } \\
\text { et al., } \\
\text { (2019) }\end{array}$ & $71 \%$ & 1 & $0.5^{b}$ & 1 & 1 & 1 & 1 & 1 & $0.5^{c}$ & $0.5^{\mathrm{d}}$ & 1 & $0.5^{\mathrm{e}}$ & NA & 1 & 1 & 1 & 0 & 1 & 0 & 1 & 0 & 0 & 1 & 1 & 1 \\
\hline \multicolumn{27}{|c|}{ Cervical cancer } \\
\hline 18 & $\begin{array}{c}\text { Baena- } \\
\text { Cañada } \\
\text { et al., } \\
(2013)\end{array}$ & $60 \%$ & 0 & 0 & 1 & 1 & 1 & 0 & 1 & $0.5^{c}$ & NA & 1 & $0.5^{\mathrm{e}}$ & 1 & 1 & 1 & NA & NA & NA & 0 & 0 & 0 & 0 & 1 & 1 & 1 \\
\hline 19 & $\begin{array}{c}\text { Auguste } \\
\text { et al., } \\
\text { (2014) }\end{array}$ & $94 \%$ & 1 & $0.5^{b}$ & 1 & 1 & 1 & 1 & 1 & 1 & 1 & 1 & 1 & 1 & 1 & 1 & 1 & 1 & 1 & 1 & 1 & 1 & 0 & 1 & 1 & 1 \\
\hline \multicolumn{27}{|c|}{ Head and neck cancer } \\
\hline 21 & $\begin{array}{l}\text { Meregaglia } \\
\text { et al., } \\
(2018)\end{array}$ & $90 \%$ & 1 & $0.5^{b}$ & 1 & 1 & 1 & 1 & 1 & $0.5^{c}$ & $0.5^{c}$ & 1 & 1 & 1 & 1 & 1 & 1 & 1 & 1 & 1 & 1 & 1 & 0 & 1 & 1 & 1 \\
\hline \multicolumn{27}{|c|}{ Hodgkin's disease } \\
\hline 22 & $\begin{array}{c}\text { Dryver } \\
\text { et al., } \\
(2003)\end{array}$ & $48 \%$ & $0.5^{\mathrm{a}}$ & $0.5^{b}$ & 1 & 1 & 1 & 0 & 0 & 1 & NA & 1 & $0.5^{\mathrm{e}}$ & NA & 1 & 1 & NA & NA & NA & 0 & 0 & 0 & 0 & 1 & 0 & 0 \\
\hline 23 & $\begin{array}{l}\text { Guadagnolo } \\
\text { et al., } \\
\text { (2006) }\end{array}$ & $88 \%$ & 1 & $0.5^{b}$ & 1 & 1 & 1 & 1 & 1 & $0.5^{c}$ & 1 & 1 & 1 & 1 & 1 & 1 & 1 & 1 & 1 & 1 & 1 & 0 & 0 & 1 & 1 & 1 \\
\hline \multicolumn{27}{|c|}{ Testicular cancer } \\
\hline 24 & $\begin{array}{l}\text { Clasen } \\
\text { et al., } \\
\text { (2009) }\end{array}$ & $48 \%$ & $0.5^{\mathrm{a}}$ & 0 & 1 & 1 & 1 & 0 & 0 & $0.5^{c}$ & NA & 1 & $0.5^{\mathrm{e}}$ & NA & 1 & 1 & NA & NA & NA & 0 & 0 & 0 & 1 & 1 & 0 & 0 \\
\hline
\end{tabular}


Table A7. Cont.

\begin{tabular}{|c|c|c|c|c|c|c|c|c|c|c|c|c|c|c|c|c|c|c|c|c|c|c|c|c|c|c|}
\hline & & & $\begin{array}{c}\text { Item } \\
1\end{array}$ & $\begin{array}{c}\text { Item } \\
2\end{array}$ & $\begin{array}{c}\text { Item } \\
3\end{array}$ & $\begin{array}{c}\text { Item } \\
4\end{array}$ & $\begin{array}{c}\text { Item } \\
5\end{array}$ & $\begin{array}{c}\text { Item } \\
6\end{array}$ & $\begin{array}{c}\text { Item } \\
7\end{array}$ & $\begin{array}{c}\text { Item } \\
8\end{array}$ & $\begin{array}{l}\text { Item } \\
9\end{array}$ & $\begin{array}{c}\text { Item } \\
10\end{array}$ & $\begin{array}{c}\text { Item } \\
11\end{array}$ & $\begin{array}{c}\text { Item } \\
12\end{array}$ & $\begin{array}{c}\text { Item } \\
13\end{array}$ & $\begin{array}{c}\text { Item } \\
14\end{array}$ & $\begin{array}{c}\text { Item } \\
15\end{array}$ & $\begin{array}{c}\text { Item } \\
16\end{array}$ & $\begin{array}{c}\text { Item } \\
17\end{array}$ & $\begin{array}{c}\text { Item } \\
18\end{array}$ & $\begin{array}{c}\text { Item } \\
19\end{array}$ & $\begin{array}{c}\text { Item } \\
20\end{array}$ & $\begin{array}{c}\text { Item } \\
21\end{array}$ & $\begin{array}{c}\text { Item } \\
22\end{array}$ & $\begin{array}{l}\text { Item } \\
23\end{array}$ & $\begin{array}{l}\text { Item } \\
24\end{array}$ \\
\hline \multicolumn{3}{|c|}{ Charytonowicz } & & & & & & & & & & & & & & & & & & & & & & & & \\
\hline 25 & $\begin{array}{l}\text { et al., } \\
\text { (2019) }\end{array}$ & $79 \%$ & 1 & $0.5^{b}$ & 1 & 1 & 1 & 1 & 1 & 1 & 1 & 1 & $0.5^{\mathrm{e}}$ & NA & 1 & 1 & 1 & 1 & 1 & 1 & 0 & 0 & 0 & 1 & 1 & 1 \\
\hline \multicolumn{27}{|c|}{ Others } \\
\hline 26 & $\begin{array}{c}\text { Gilbert } \\
\text { et al., } \\
(2000)\end{array}$ & $48 \%$ & 0 & $0.5^{b}$ & 1 & 1 & 1 & 0 & 1 & $0.5^{c}$ & NA & 1 & $0.5^{\mathrm{e}}$ & NA & 1 & 1 & NA & NA & NA & 0 & 0 & 0 & 0 & 1 & 0 & 0 \\
\hline 28 & $\begin{array}{l}\text { C. R. Ret- } \\
\text { tenmaier } \\
\text { et al., } \\
(2010)\end{array}$ & $45 \%$ & $0.5^{\mathrm{a}}$ & $0.5^{b}$ & 1 & 1 & 1 & 0 & 0 & $0.5^{c}$ & NA & 1 & $0.5^{\mathrm{e}}$ & NA & 1 & 1 & NA & NA & NA & 0 & 0 & 0 & 0 & 1 & 0 & 0 \\
\hline 29 & $\begin{array}{l}\text { N. Retten- } \\
\text { maier } \\
\text { et al., } \\
(2010)\end{array}$ & $50 \%$ & $0.5^{\mathrm{a}}$ & $0.5^{b}$ & 1 & 1 & 1 & 0 & 0 & $0.5^{c}$ & NA & 1 & $0.5^{\mathrm{e}}$ & NA & 1 & 1 & NA & NA & NA & 0 & 0 & 0 & 0 & 1 & 1 & 0 \\
\hline 31 & $\begin{array}{c}\text { Dansk } \\
\text { et al., } \\
\text { (2016) }\end{array}$ & $90 \%$ & 1 & $0.5^{b}$ & 1 & 1 & 1 & 1 & 1 & 1 & $0.5^{c}$ & 1 & $0.5^{\mathrm{e}}$ & NA & 1 & 1 & 1 & 1 & 1 & 1 & 1 & 1 & 1 & 1 & 1 & 1 \\
\hline 32 & $\begin{array}{c}\text { Pearce } \\
\text { et al., } \\
\text { (2016) }\end{array}$ & $98 \%$ & 1 & $0.5^{b}$ & 1 & 1 & 1 & 1 & 1 & 1 & 1 & 1 & 1 & 1 & 1 & 1 & 1 & 1 & 1 & 1 & 1 & 1 & 1 & 1 & 1 & 1 \\
\hline 33 & $\begin{array}{l}\text { Gao et al., } \\
\text { (2017) }\end{array}$ & $94 \%$ & 1 & $0.5^{b}$ & 1 & 1 & 1 & 1 & 1 & $0.5^{c}$ & $0.5^{c}$ & 1 & 1 & 1 & 1 & 1 & 1 & 1 & 1 & 1 & 1 & 1 & 1 & 1 & 1 & 1 \\
\hline 34 & $\begin{array}{c}\text { Ehrhardt } \\
\text { et al., } \\
(2020)\end{array}$ & $90 \%$ & 1 & $0.5^{b}$ & 1 & 1 & 1 & 0 & 1 & 1 & 1 & 1 & 1 & 1 & 1 & 1 & 1 & 1 & 1 & 1 & 1 & 1 & 0 & 1 & 1 & 1 \\
\hline
\end{tabular}

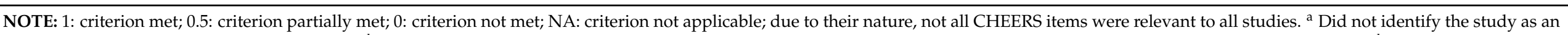

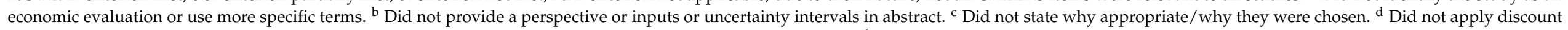

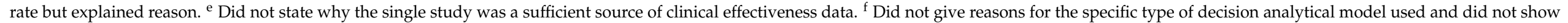
the model structure. ${ }^{\mathrm{g}}$ Assumption was not described. ${ }^{\mathrm{h}}$ Non-parametric bootstrapping was used. ${ }^{\mathrm{i}}$ Did not discuss limitations. 


\section{References}

1. Ferlay, J.; Soerjomataram, I.; Dikshit, R.; Eser, S.; Mathers, C.; Rebelo, M.; Parkin, D.M.; Forman, D.; Bray, F. Cancer incidence and mortality worldwide: Sources, methods and major patterns in GLOBOCAN 2012. Int. J. Cancer 2015, 136, E359-E386. [CrossRef]

2. AIHW, "Cancer data in Australia," Australian Institute of Health and Welfare, Canberra, Australia. 2021. Available online: https:/ / www.aihw.gov.au/reports/cancer/cancer-data-in-australia/contents/cancer-survival-data-visualisation (accessed on 23 July 2021).

3. OECD, "Health Care Quality Indicators: Cancer Care," Organisation for Economic Co-operation and Development Online. 2021. Available online: https:/ / stats.oecd.org/Index.aspx?DataSetCode=HEALTH_LTCR (accessed on 26 July 2021).

4. Shapiro, C.L. Cancer Survivorship. N. Engl. J. Med. 2018, 379, 2438-2450. [CrossRef] [PubMed]

5. Siegel, R.L.; Miller, K.D.; Fuchs, H.E.; Jemal, A. Cancer Statistics, 2021. CA A Cancer J. Clin. 2021, 71, 7-33.

6. Graves, N. Make economics your friend. J. Hosp. Infect. 2018, 100, 123-129. [CrossRef]

7. Frew, E.; Breheny, K. Health economics methods for public health resource allocation: A qualitative interview study of decision makers from an English local authority. Health Economics. Policy Law 2020, 15, 128-140. [CrossRef] [PubMed]

8. Cheng, Q.; Graves, N.; Pacella, R.E. Economic evaluations of guideline-based care for chronic wounds: A systematic review. Appl. Health Econ. Health Policy 2018, 16, 633-651. [CrossRef]

9. McCreanor, V.; Graves, N.; Barnett, A.G.; Parsonage, W.; Merlo, G. A systematic review and critical analysis of cost-effectiveness studies for coronary artery disease treatment. F1000Research 2018, 7, 77. [CrossRef]

10. Gubler-Gut, B.E.; Pöhlmann, J.; Flatz, A.; Schwenkglenks, M.; Rohrmann, S. Cost-effectiveness of physical activity interventions in cancer survivors of developed countries: A systematic review. J. Cancer Surviv. 2021, 15, 961-975. [CrossRef]

11. Page, M.J.; McKenzie, J.E.; Bossuyt, P.M.; Boutron, I.; Hoffmann, T.C.; Mulrow, C.D.; Shamseer, L.; Tetzlaff, J.M.; Moher, D. Updating guidance for reporting systematic reviews: Development of the PRISMA 2020 statement. J. Clin. Epidemiol. 2021, 134, 103-112. [CrossRef]

12. Marzorati, C.; Riva, S.; Pravettoni, G. Who is a cancer survivor? A systematic review of published definitions. J. Cancer Educ. 2017, 32, 228-237. [CrossRef]

13. Denlinger, C.S.; Carlson, R.W.; Are, M.; Baker, K.S.; Davis, E.; Edge, S.B.; Friedman, D.L.; Goldman, M.; Jones, L.; King, A. Survivorship: Introduction and definition. J. Natl. Compr. Canc. Netw. 2014, 12, 34-45. [CrossRef] [PubMed]

14. Bessen, T.; Keefe, D.M.; Karnon, J. Does one size fit all? Cost utility analyses of alternative mammographic follow-up schedules, by risk of recurrence. Int. J. Technol. Assess. Health Care Jan. 2015, 31, 281-288. [CrossRef]

15. Bessen, T.; Karnon, J. A patient-level calibration framework for evaluating surveillance strategies: A case study of mammographic follow-up after early breast cancer. Value Health 2014, 17, 669-678. [CrossRef]

16. Husereau, D.; Drummond, M.; Petrou, S.; Carswell, C.; Moher, D.; Greenberg, D.; Augustovski, F.; Briggs, A.H.; Mauskopf, J.; Loder, E. Consolidated health economic evaluation reporting standards (CHEERS) statement. Cost Eff. Res. Alloc. 2013, 11, 6. [CrossRef]

17. Husereau, D.; Drummond, M.; Petrou, S.; Carswell, C.; Moher, D.; Greenberg, D.; Augustovski, F.; Briggs, A.H.; Mauskopf, J.; Loder, E. Consolidated Health Economic Evaluation Reporting Standards (CHEERS)—Explanation and Elaboration: A Report of the ISPOR Health Economic Evaluation Publication Guidelines Good Reporting Practices Task Force. Value Health 2013, 16, e1-e5. [CrossRef]

18. Bleeker, W.A.; Mulder, N.H.; Hermans, J.; Otter, R.; Plukker, J.T. Value and cost of follow-up after adjuvant treatment of patients with Dukes' C colonic cancer. Br. J. Surg. 2001, 88, 101-106. [CrossRef] [PubMed]

19. Di Cristofaro, L.; Scarpa, M.; Angriman, I.; Perissinotto, E.; Ruffolo, C.; Frego, M.; Erroi, F. Cost-effectiveness analysis of postoperative surveillance protocols following radical surgery for colorectal cancer. Acta Chir. Belg. 2012, 112, 24-32. [CrossRef]

20. Staib, L.; Link, K.H.; Beger, H.G. Follow-up in colorectal cancer: Cost-effectiveness analysis of established and novel concepts. Langenbeck's Arch. Surg. 2000, 385, 412-420. [CrossRef] [PubMed]

21. Borie, F.; Combescure, C.; Daurès, J.-P.; Trétarre, B.; Millat, B. Cost-effectiveness of two follow-up strategies for curative resection of colorectal cancer: Comparative study using a Markov model. World. J. Surg. 2004, 28, 563-569. [CrossRef]

22. Macafee, D.A.; Whynes, D.K.; Scholefield, J.H. Risk-stratified intensive follow up for treated colorectal cancer - realistic and cost saving? Colorectal Dis. 2008, 10, 222-230. [CrossRef]

23. Mant, D.; Gray, A.; Pugh, S.; Campbell, H.; George, S.; Fuller, A.; Shinkins, B.; Corkhill, A.; Mellor, J.; Dixon, E.; et al. A randomised controlled trial to assess the cost-effectiveness of intensive versus no scheduled follow-up in patients who have undergone resection for colorectal cancer with curative intent. Health Technol. Assess. 2017, 21, 1-86. [CrossRef]

24. Renehan, A.G.; O'Dwyer, S.T.; Whynes, D.K. Cost effectiveness analysis of intensive versus conventional follow up after curative resection for colorectal cancer. BMJ 2004, 328, 81. [CrossRef] [PubMed]

25. Téhard, B.; Detournay, B.; Borget, I.; Roze, S.; De Pouvourville, G. Value of a QALY for France: A New Approach to Propose Acceptable Reference Values. Value Health 2020, 23, 985-993. [CrossRef] [PubMed]

26. Grogan, M.; Rangan, A.; Gebski, V.; Boyages, J. The value of follow-up of patients with early breast cancer treated with conservative surgery and radiation therapy. Breast 2002, 11, 163-169. [CrossRef] [PubMed] 
27. Kokko, R.; Hakama, M.; Holli, K. Follow-up cost of breast cancer patients with localized disease after primary treatment: A randomized trial. Breast Cancer Res. Treat. 2005, 93, 255-260. [CrossRef]

28. Robertson, C.; Arcot Ragupathy, S.K.; Boachie, C.; Dixon, J.M.; Fraser, C.; Hernández, R.; Heys, S.; Jack, W.; Kerr, G.R.; Lawrence, G.; et al. The clinical effectiveness and cost-effectiveness of different surveillance mammography regimens after the treatment for pri-mary breast cancer: Systematic reviews registry database analyses and economic evaluation. Health Technol. Assess. 2011, 15, 1-322. [CrossRef]

29. Lu, W.; Greuter, M.J.; Schaapveld, M.; Vermeulen, K.M.; Wiggers, T.; de Bock, G.H. Safety and cost-effectiveness of shortening hospital follow-up after breast cancer treatment. Br. J. Surg. 2012, 99, 1227-1233. [CrossRef]

30. Hengge, U.R.; Wallerand, A.; Stutzki, A.; Kockel, N. Cost-effectiveness of reduced follow-up in malignant melanoma. J. Dtsch. Derm. Ges. 2007, 5, 898-907. [CrossRef]

31. Leiter, U.; Marghoob, A.A.; Lasithiotakis, K.; Eigentler, T.K.; Meier, F.; Meisner, C.; Garbe, C. Costs of the detection of metastases and follow-up examinations in cutaneous melanoma. Melanoma Res. 2009, 19, 50-57. [CrossRef]

32. Podlipnik, S.; Moreno-Ramírez, D.; Carrera, C.; Barreiro, A.; Manubens, E.; Ferrandiz-Pulido, L.; Sánchez, M.; Vidal-Sicart, S.; Malvehy, J.; Puig, S. Cost-effectiveness analysis of imaging strategy for an intensive follow-up of patients with American Joint Committee on Cancer stage IIB, IIC and III malignant melanoma. Br. J. Derm. 2019, 180, 1190-1197. [CrossRef]

33. Forni, F.; Ferrandina, G.; Deodato, F.; Macchia, G.; Morganti, A.G.; Smaniotto, D.; Luzi, S.; D’Agostino, G.; Valentini, V.; Cellini, N. Squamous cell carcinoma antigen in follow-up of cervical cancer treated with radiotherapy: Evaluation of cost-effectiveness. Int J. Radiat Oncol. Biol. Phys. 2007, 69, 1145-1149. [CrossRef]

34. Baena-Cañada, J.M.; Ramírez-Daffós, P.; Cortés-Carmona, C.; Rosado-Varela, P.; Nieto-Vera, J.; Benítez-Rodríguez, E. Follow-up of long-term survivors of breast cancer in primary care versus specialist attention. Fam Pr. 2013, 30, 525-532. [CrossRef]

35. Auguste, P.; Barton, P.; Meads, C.; Davenport, C.; Małysiak, S.; Kowalska, M.; Zapalska, A.; Guest, P.; Martin-Hirsch, P.; Borowiack, E.; et al. Evaluating PET-CT in routine surveillance and follow-up after treatment for cervical cancer: A cost-effectiveness analysis. BJOG 2014, 121, 464-476. [CrossRef]

36. Meads, C.; Davenport, C.; Małysiak, S.; Kowalska, M.; Zapalska, A.; Guest, P.; Martin-Hirsch, P.; Borowiack, E.; Auguste, P.; Barton, P. Evaluating PET-CT in the detection and management of recurrent cervical cancer: Systematic reviews of diagnostic accuracy and subjective elicitation. Int. J. Gynaecol. Obs. 2014, 121, 398-407. [CrossRef]

37. Shah, K.; Te Marvelde, L.; Collins, M.; De Abreu Lourenco, R.; D’Costa, I.; Coleman, A.; Fua, T.; Liu, C.; Rischin, D.; Lau, E.; et al. Safety and cost analysis of an (18)FDG-PET-CT response based follow-up strategy for head and neck cancers treated with primary radiation or chemoradiation. Oral Oncol. 2015, 51, 529-535. [CrossRef]

38. Meregaglia, M.; Cairns, J.; Licitra, L.; Bossi, P. The use of intensive radiological assessments in routine surveillance after treatment for head and neck cancer: An economic evaluation. Eur. J. Cancer 2018, 93, 89-98. [CrossRef]

39. Dryver, E.T.; Jernström, H.; Tompkins, K.; Buckstein, R.; Imrie, K.R. Follow-up of patients with Hodgkin's disease following curative treatment: The routine CT scan is of little value. Br. J. Cancer 2003, 89, 482-486. [CrossRef]

40. Guadagnolo, B.A.; Punglia, R.S.; Kuntz, K.M.; Mauch, P.M.; Ng, A.K. Cost-effectiveness analysis of computerized tomography in the routine follow-up of patients after primary treatment for Hodgkin's disease. J. Clin. Oncol. 2006, 24, 4116-4122. [CrossRef] [PubMed]

41. Clasen, J.; Schmidberger, H.; Souchon, R.; Weissbach, L.; Hartmann, M.; Hartmann, J.T.; Hehr, T.; Bamberg, M. What is the value of routine follow-up in stage I seminoma after paraaortic radiotherapy? An analysis of the German Testicular Cancer Study Group (GTCSG) in 675 prospectively followed patients. Strahlenther. Onkol. 2009, 185, 349-354. [CrossRef] [PubMed]

42. Charytonowicz, D.; Aubrey, H.; Bell, C.; Ferret, M.; Tsui, K.; Atfield, R.; Coleman, N.; Murray, M.J.; Wilson, E.C.F. Cost Analysis of Noninvasive Blood-Based MicroRNA Testing Versus CT Scans for Follow-up in Patients With Testicular Germ-Cell Tumors. Clin. Genitourin. Cancer 2019, 17, e733-e744. [CrossRef] [PubMed]

43. Gilbert, S.; Reid, K.R.; Lam, M.Y.; Petsikas, D. Who should follow up lung cancer patients after operation? Ann. Thorac. Surg. 2000, 69, 1696-1700. [CrossRef]

44. Dion, M.; Martínez, C.H.; Williams, A.K.; Chalasani, V.; Nott, L.; Pautler, S.E. Cost analysis of two follow-up strategies for localized kidney cancer: A Canadian cohort comparison. Can. Urol. Assoc. J. 2010, 4, 322. [CrossRef]

45. Rettenmaier, C.R.; Rettenmaier, N.B.; Wojciechowski, T.; Abaid, L.N.; Brown, J.V., III; Micha, J.P.; Goldstein, B.H. The utility of routine follow-up procedures in the surveillance of uterine cancer: A 20-year institutional review. Oncology 2010, 79, 262-268. [CrossRef]

46. Rettenmaier, N.; Rettenmaier, C.; Wojciechowski, T.; Abaid, L.; Brown, J., III; Micha, J.; Goldstein, B. The utility and cost of routine follow-up procedures in the surveillance of ovarian and primary peritoneal carcinoma: A 16-year institutional review. Br. J. Cancer 2010, 103, 1657-1662. [CrossRef] [PubMed]

47. Imran, S.A.; Chu, K.; Rajaraman, M.; Rajaraman, D.; Ghosh, S.; De Brabandere, S.; Kaiser, S.M.; Van Uum, S. Primary versus Tertiary Care Follow-Up of Low-Risk Differentiated Thyroid Cancer: Real-World Comparison of Outcomes and Costs for Patients and Health Care Systems. Eur. Thyroid. J. 2019, 8, 208-214. [CrossRef] [PubMed]

48. Dansk, V.; Malmström, P.U.; Bläckberg, M.; Malmenäs, M. Hexaminolevulinate hydrochloride blue-light flexible cystoscopy in the detection and follow-up of nonmuscle-invasive bladder cancer: Cost consequences during outpatient surveillance in Sweden. Future Oncol. 2016, 12, 1025-1038. [CrossRef] [PubMed] 
49. Pearce, A.M.; Ryan, F.; Drummond, F.J.; Thomas, A.A.; Timmons, A.; Sharp, L. Comparing the costs of three prostate cancer follow-up strategies: A cost minimisation analysis. Supportive Care Cancer 2016, 24, 879-886. [CrossRef]

50. Gao, L.; Moodie, M.; Brown, V.; Avery, S. Cost-effectiveness of a lifestyle modification program in long-term survivors of hemopoietic stem cell transplantation. Clin. Transplant. 2017, 31, e13049-e13059. [CrossRef]

51. Ehrhardt, M.J.; Ward, Z.J.; Liu, Q.; Chaudhry, A.; Nohria, A.; Border, W.; Fulbright, J.M.; Mulrooney, D.A.; Oeffinger, K.C.; Nathan, P.C. Cost-Effectiveness of the International Late Effects of Childhood Cancer Guideline Harmonization Group Screening Guidelines to Prevent Heart Failure in Survivors of Childhood Cancer. J. Clin. Oncol. 2020, 33, 3851-3862. [CrossRef] [PubMed]

52. Mulrooney, D.A.; Hyun, G.; Ness, K.K.; Ehrhardt, M.J.; Yasui, Y.; Duprez, D.; Howell, R.M.; Leisenring, W.M.; Constine, L.S.; Tonorezos, E. Major cardiac events for adult survivors of childhood cancer diagnosed between 1970 and 1999: Report from the Childhood Cancer Survivor Study cohort. BMJ 2020, 368, 16794. [CrossRef]

53. Draeger, T.; Voelkel, V.; Groothuis-Oudshoorn, C.G.M.; Lavric, M.; Veltman, J.; Dassen, A.; Boersma, L.J.; Witteveen, A.; Sonke, G.S.; Koffijberg, H.; et al. Applying Risk-Based Follow-Up Strategies on the Dutch Breast Cancer Population: Consequences for Care and Costs. Value Health 2020, 23, 1149-1156. [CrossRef] [PubMed]

54. Augestad, K.M.; Norum, J.; Dehof, S.; Aspevik, R.; Ringberg, U.; Nestvold, T.; Vonen, B.; Skrøvseth, S.O.; Lindsetmo, R.O. Cost-effectiveness and quality of life in surgeon versus general practitioner-organised colon cancer surveillance: A randomised controlled trial. BMJ Open 2013, 3, e002391. [CrossRef] [PubMed]

55. Verberne, C.J.; Wiggers, T.; Grossmann, I.; de Bock, G.H.; Vermeulen, K.M. Cost-effectiveness of a carcinoembryonic antigen (CEA) based follow-up programme for colorectal cancer (the CEA Watch trial). Colorectal. Dis. 2016, 18, O91-O96. [CrossRef] [PubMed]

56. Beaver, K.; Hollingworth, W.; McDonald, R.; Dunn, G.; Tysver-Robinson, D.; Thomson, L.; Hindley, A.C.; Susnerwala, S.S.; Luker, K. Economic evaluation of a randomized clinical trial of hospital versus telephone follow-up after treatment for breast cancer. Br. J. Surg. 2009, 96, 1406-1415. [CrossRef] [PubMed]

57. Benning, T.M.; Kimman, M.L.; Dirksen, C.D.; Boersma, L.J.; Dellaert, B.G.C. Combining individual-level discrete choice experiment estimates and costs to inform health care management decisions about customized care: The case of follow-up strategies after breast cancer treatment. Value Health 2012, 15, 680-689. [CrossRef] [PubMed]

58. Burm, R.; Thewes, B.; Rodwell, L.; Kievit, W.; Speckens, A.; van de Wal, M.; Prins, J. Long-term efficacy and cost-effectiveness of blended cognitive behavior therapy for high fear of recurrence in breast, prostate and colorectal Cancer survivors: Follow-up of the SWORD randomized controlled trial. BMC Cancer 2019, 19, 462. [CrossRef] [PubMed]

59. Coyle, D.; Grunfeld, E.; Coyle, K.; Pond, G.; Julian, J.A.; Levine, M.N. Cost effectiveness of a survivorship care plan for breast cancer survivors. J. Oncol. Pr. 2014, 10, e86-e92. [CrossRef]

60. Kimman, M.L.; Dirksen, C.D.; Voogd, A.C.; Falger, P.; Gijsen, B.C.M.; Thuring, M.; Lenssen, A.; van der Ent, F.; Verkeyn, J.; Haekens, C.; et al. Economic evaluation of four follow-up strategies after curative treatment for breast cancer: Results of an RCT. Eur. J. Cancer 2011, 47, 1175-1185. [CrossRef]

61. Oltra, A.; Santaballa, A.; Munárriz, B.; Pastor, M.; Montalar, J. Cost-benefit analysis of a follow-up program in patients with breast cancer: A randomized prospective study. Breast. J. 2007, 13, 571-574. [CrossRef]

62. Wojcinski, S.; Farrokh, A.; Hille, U.; Hirschauer, E.; Schmidt, W.; Hillemanns, P.; Degenhardt, F. Optimizing breast cancer follow-up: Diagnostic value and costs of additional routine breast ultrasound. Ultrasound Med. Biol. 2011, 37, 198-206. [CrossRef]

63. Armstrong, A.; Otvos, B.; Singh, S.; Debernardo, R. Evaluation of the cost of CA- 125 measurement, physical exam, and imaging in the diagnosis of recurrent ovarian cancer. Gynecol. Oncol. 2013, 131, 503-507. [CrossRef] [PubMed]

64. Dixon, P.; Beaver, K.; Williamson, S.; Sutton, C.; Martin-Hirsch, P.; Hollingworth, W. Cost-Consequence Analysis Alongside a Randomised Controlled Trial of Hospital Versus Telephone Follow-Up after Treatment for Endometrial Cancer. Appl. Health Econ. Health Policy 2018, 16, 415-427. [CrossRef] [PubMed]

65. Ham, J.C.; Driessen, C.M.; Hendriks, M.P.; Fiets, E.; Kreike, B.; Hoeben, A.; Slingerland, M.; van Opstal, C.C.; Kullberg, B.J.; Jonker, M.A.; et al. Prophylactic antibiotics reduce hospitalisations and cost in locally advanced head and neck cancer patients treated with chemoradiotherapy: A randomised phase 2 study. Eur. J. Cancer 2019, 113, 32-40. [CrossRef]

66. Bongers, V.; Hobbelink, M.G.; van Rijk, P.P.; Hordijk, G.J. Cost-effectiveness of dual-head 18F-fluorodeoxyglucose PET for the detection of recurrent laryngeal cancer. Cancer Biother. Radiopharm. 2002, 17, 303-306. [CrossRef] [PubMed]

67. Greuter, M.J.; Schouten, C.S.; Castelijns, J.A.; de Graaf, P.; Comans, E.F.; Hoekstra, O.S.; de Bree, R.; Coupé, V.M. Cost-effectiveness of response evaluation after chemoradiation in patients with advanced oropharyngeal cancer using 18 F-FDG-PET-CT and/or diffusion-weighted MRI. BMC Cancer 2017, 17, 256. [CrossRef]

68. Heinzel, A.; Müller, D.; Yekta-Michael, S.S.; Ceccon, G.; Langen, K.-J.; Mottaghy, F.M.; Wiesmann, M.; Kocher, M.; Hattingen, E.; Galldiks, N. O-(2-18F-fluoroethyl)-L-tyrosine PET for evaluation of brain metastasis recurrence after radiotherapy: An effectiveness and cost-effectiveness analysis. Neuro-Oncol. 2017, 19, 1271-1278. [CrossRef]

69. Jeyarajah, S.; Adams, K.; Higgins, L.; Ryan, S.; Leather, A.; Papagrigoriadis, S. Prospective evaluation of a colorectal cancer nurse follow-up clinic. Colorectal. Dis. 2011, 13, 31-38. [CrossRef]

70. Kampshoff, C.S.; van Dongen, J.M.; van Mechelen, W.; Schep, G.; Vreugdenhil, A.; Twisk, J.W.R.; Bosmans, J.E.; Brug, J.; Chinapaw, M.J.M.; Buffart, L.M. Long-term effectiveness and cost-effectiveness of high versus low-to-moderate intensity resistance and endurance exercise interventions among cancer survivors. J. Cancer Surviv. 2018, 12, 417-429. [CrossRef] 
71. Kent, M.S.; Korn, P.; Port, J.L.; Lee, P.C.; Altorki, N.K.; Korst, R.J. Cost effectiveness of chest computed tomography after lung cancer resection: A decision analysis model. Ann. Thorac. Surg. 2005, 80, 1215-1222, discussion 1222-3. [CrossRef]

72. Lizée, T.; Basch, E.; Trémolières, P.; Voog, E.; Domont, J.; Peyraga, G.; Urban, T.; Bennouna, J.; Septans, A.L.; Balavoine, M.; et al. Cost-Effectiveness of Web-Based Patient-Reported Outcome Surveillance in Patients With Lung Cancer. J. Thorac. Oncol. 2019, 14, 1012-1020. [CrossRef]

73. Moore, S.; Corner, J.; Haviland, J.; Wells, M.; Salmon, E.; Normand, C.; Brada, M.; O’Brien, M.; Smith, I. Nurse led follow up and conventional medical follow up in management of patients with lung cancer: Randomised trial. BMJ 2002, 325, 1145. [CrossRef] [PubMed]

74. Nam, R.K.; Redelmeier, D.A.; Spiess, P.E.; Sampson, H.A.; Fradet, Y.; Jewett, M.A. Comparison of molecular and conventional strategies for followup of superficial bladder cancer using decision analysis. J. Urol. 2000, 163, 752-757. [CrossRef]

75. Polinder, S.; Verschuur, E.M.L.; Siersema, P.D.; Kuipers, E.J.; Steyerberg, E.W. Cost comparison study of two different follow-up protocols after surgery for oesophageal cancer. Eur. J. Cancer 2009, 45, 2110-2115. [CrossRef]

76. Pollack, C.E.; Frick, K.D.; Herbert, R.J.; Blackford, A.L.; Neville, B.A.; Wolff, A.C.; Carducci, M.A.; Earle, C.C.; Snyder, C.F. It's who you know: Patient-sharing, quality, and costs of cancer survivorship care. J. Cancer Surviv. 2014, 8, 156-166. [CrossRef] [PubMed]

77. Shih, S.T.F.; Butow, P.; Bowe, S.J.; Thewes, B.; Turner, J.; Gilchrist, J.; Mihalopoulos, C. Cost-effectiveness of an intervention to reduce fear of cancer recurrence: The Conquerfear randomized controlled trial. Psycho-Oncol. 2019, 28, 1071-1079. [CrossRef]

78. van der Spek, N.; Jansen, F.; Holtmaat, K.; Vos, J.; Breitbart, W.; van Uden-Kraan, C.F.; Tollenaar, R.A.E.M.; Cuijpers, P.; Coupé, V.M.H.; Verdonck-de Leeuw, I.M. Cost-utility analysis of meaning-centered group psychotherapy for cancer survivors. Psycho-Oncol. 2018, 27, 1772-1779. [CrossRef]

79. van Dongen, J.M.; Persoon, S.; Jongeneel, G.; Bosmans, J.E.; Kersten, M.J.; Brug, J.; Nollet, F.; Chinapaw, M.J.M.; Buffart, L.M. Long-term effectiveness and cost-effectiveness of an 18-week supervised exercise program in patients treated with autologous stem cell transplantation: Results from the EXIST study. J. Cancer Surviv. 2019, 13, 558-569. [CrossRef]

80. van Loon, J.; Grutters, J.P.; Wanders, R.; Boersma, L.; Dingemans, A.M.; Bootsma, G.; Geraedts, W.; Pitz, C.; Simons, J.; Brans, B.; et al. 18FDG-PET-CT in the follow-up of non-small cell lung cancer patients after radical radiotherapy with or without chemotherapy: An economic evaluation. Eur. J. Cancer 2010, 46, 110-119. [CrossRef] 